\title{
Hipolit jako Edyp: reinterpretacja mitu w powieści Antoniego Libery Madame
}

\begin{abstract}
Stróżyński Mateusz, Hipolit jako Edyp: reinterpretacja mitu w powieści Antoniego Libery Madame [Hippolytus as Oedipus: a reinterpretation of the myth in Antoni Libera's novel Madame]. „Przestrzenie Teorii” 30. Poznań 2018, Adam Mickiewicz University Press, pp. 79-111. ISSN 1644-6763. DOI 10.14746/pt.2018.30.4.
\end{abstract}

The article is a psychoanalytically oriented analysis of the use of the myth of Hippolytus and Phaedra in A. Libera's novel Madame. The function of the myth in the novel is presented in terms of the categories of reinterpretation and prefiguration as well as in the context of its ancient sources. Libera brings together the myth of Hippolytus and the myth of Oedipus by emphasizing the role of the symbolic mother and the narrative constitutes a defense against both Oedipal and pre-Oedipal conflicts. The end of the novel is an attempt at a positive resolution of the Oedipal tensions in the narrative by means of sublimation and symbolization, in the context of the Freudian conception of drives and culture.

KEYWORDS: Antoni Libera, Madame, myth, psychoanalysis, culture, Sigmund Freud, Hippolytus, Oedipus

Zarówno sam Antoni Libera, jak i recenzenci jego powieści Madame podkreślali rolę, jaką odgrywa w niej mit, a właściwie tworzenie mitu ${ }^{1}$. W tym przypadku jednak to pojęcie rozumiane jest bardzo szeroko. W niniejszym artykule zaproponuje analizę tego, w jaki sposób Antoni Libera dokonuje reinterpretacji ${ }^{2}$ mitu Hipolita i Fedry. Jego obecność u Libery zapośredniczona jest głównie przez tragedię Racine’a Fedra, ale w pewnym stopniu, jak się wydaje, także przez dwa wybitne dramaty: Eurypidesa i Seneki. Ze względu na bogactwo wątków występujących w powieści Madame w niniejszym artykule skupię się jedynie na symbolicznej relacji młodzieńca do postaci macierzyńskiej, wyrażonej w miłości bohatera do jego nauczycielki francuskiego i dyrektorki szkoły.

Stanisław Stabryła wskazał na trzy główne formy obecności mitu w literaturze: renarrację lub rewokację, reinterpretację i prefigurację. Renarrację lub rewokację zdefiniował jako proste powtórzenie mitu lub motywów

${ }^{1}$ Np. S. Cichowicz, Owoc słodkiej fikcji, „Nowe Książki” 1999, nr 1, s. 10-11; D. Ulicka, Czekanie na opowieść, „Nowe Książki” 1999, nr 1, s. 10-11; Żart, ironia, muzyka i gtębsze znaczenie. Z Antonim Libera rozmawia Władysław Rajcher, „Nowe Książki” 1999, nr 1, s. 8.

${ }^{2}$ Używam tego pojęcia w sensie, w jakim pojawia się ono w tekstach Henryka Markiewicza (Literatura a mity, [w:] H. Markiewicz, Literaturoznawstwo i jego sqsiedztwa, Warszawa 1989, s. 71) i Stanisława Stabryły (wstęp do: tegoż, Mit, człowiek, literatura, Warszawa, 1991, s. 11-12). 
mitycznych, z którym - w kontekście omawianego mitu Hipolita - mamy do czynienia, na przykład, we wspomnianej tragedii Racine’a. Reinterpretację rozumie on jako zasadniczą zmianę sensu czy wymowy motywu mitologicznego, charakterystyczna zwłaszcza dla dzieł epoki nowożytnej. Prefiguracja wreszcie polega na takim skonstruowaniu dzieła literackiego, że istnieje w nim pewien system analogii między mitem a fabuła tego dzieła, widocznych w losach głównych bohaterów lub w strukturze świata przedstawionego. W świetle klasyfikacji Stabryły można powiedzieć, że powieść Antoniego Libery jest swego rodzaju reinterpretacją przez prefigurację, autor buduje bowiem świat analogiczny do świata mitu i sugeruje, że relacja bohatera do tytułowej Madame jest w pewien sposób podobna do relacji przedstawionej w micie Hipolita, ale zarazem dokonuje pewnych zmian, które tworzą obraz mitu wykraczający poza to, co odnajdujemy u Eurypidesa, Seneki czy Racine'a.

W niniejszym tekście dowiodę, że ta reinterpretacja przez prefigurację oparta jest w znacznej mierze na wprowadzeniu wątków mitu Edypa do mitu Hipolita, co można by określić w skrócie tak, jak to uczyniłem w tytule: Hipolit jest Edypem. Ten interesujacy zabieg nie jest całkowita nowościa - pewna zbieżność mitów Edypa i Hipolita rzuca się w oczy nawet przy powierzchownej lekturze choćby dlatego, że w obu przypadkach chodzi o relację erotyczną łączącą młodzieńca ze starsza, macierzyńską postacia, a także - o wrogą relację między ojcem i synem, skupioną wokół idei kary za tę erotyczną relację. Jeszcze bliższe powiązania między mitami Hipolita i Edypa wskazane zostały przez psychoanalityczne interpretacje mitów, toteż odwołam się tutaj do psychoanalitycznej teorii i metody interpretacyjnej, aby prześledzić, w jaki sposób Libera reinterpretuje mit i konstruuje relację głównych bohaterów powieści ${ }^{3}$. Bez względu na świadome zamiary autora Madame ta „reinterpretacja przez prefigurację”, jak się okaże pod koniec, ma wymowę głęboko zgodną z Freudowskim ujęciem nie tylko mitów, ale i literatury pięknej w ogóle.

\section{Zagadka Sfingi}

Mit o miłości Fedry do Hipolita ma strukturalne odpowiedniki w szeroko rozumianym kręgu śródziemnomorskim. W Księdze Rodzaju (Rdz 39,1-20), a później w muzułmańskich legendach o Józefie napotykamy wątek miłości

${ }^{3}$ Do języka psychoanalitycznego odwołała się stosunkowo powierzchownie Kazimiera Szczuka w swoim tekście Forma i chłopiec, „Res Publica Nowa” 1999, nr 1-2 [124-125], s. 9599. Autorka używa wprawdzie terminów takich jak gwałt czy kastracja, ale brak w tekście bardziej spójnego użycia teorii psychoanalitycznej czy analitycznej metody interpretacyjnej, której miejsce zajmują raczej feministyczne koncepcje płci. 
żony egipskiego dostojnika, Putyfara, do młodego i pięknego syna Jakuba. Młodzieniec odrzuca namiętność starszej kobiety, a ona oskarża go przed mężem o próbę gwałtu, za co Józef skazany zostaje na zamknięcie w lochach faraona. W Iliadzie znajdujemy podobną historię o Bellerofoncie (6.150-193). Bohater gości u króla Projtosa, którego żona, znana w późniejszych wersjach jako Stheneboja lub Anteja, płonie do niego żądza. Gdy młodzieniec ją odrzuca, królowa oskarża go przed mężem, że nastawał na jej cnotę. Projtos nie dokonuje zemsty sam, ale wysyła Bellerofonta do swego przyjaciela, Ojneusa, z listem, w którym prosi tego ostatniego, by doprowadził do śmierci młodzieńca. Ojneus nakłania Bellerofonta do zmierzenia się z Chimera, straszliwym potworem przypominającym lwa, kozę i orła, licząc na to, że zginie on w walce. Bellerofont jednak zabija Chimerę i w końcu uzyskuje zarówno przychylność Ojneusa, jak i rękę jego córki, podobnie jak Józef pod koniec semickiej legendy zyskuje wreszcie akceptację faraona i staje się jego prawą ręka, po tym, jak trafnie odczytuje sen o czternastu krowach.

Podobna strukturę ma mit o Hipolicie, synu Tezeusza ${ }^{4}$. Po śmierci matki Hipolita druga żona Tezeusza, Fedra (córka Pazyfae, kreteńskiej królowej, która współżyła z bykiem, oraz siostrzenica dzieciobójczej Medei), zakochuje się w młodocianym pasierbie. Kiedy Hipolit odrzuca Fedrę, ta popełnia samobójstwo, oskarżając go w liście o próbę gwałtu. Dowiedziawszy się o tym, Tezeusz skazuje syna na wygnanie i prosi swego ojca, Posejdona, by ukarał Hipolita. Bóg wysłuchuje prośby króla i podczas przejażdżki rydwanem młodzieniec zostaje zaatakowany przez straszliwego, bykokształtnego potwora, który wyłonił się z morza - traci panowanie nad końmi i ginie przez nie rozszarpany.

Eurypides jest autorem dwóch tragedii o Hipolicie - niezachowany $\mathrm{Hi}$ polit zakrywajacy twarz prawdopodobnie zawierał zabarwioną erotycznie scenę spotkania Fedry i Hipolita, a być może nawet - jak sugeruje Hanna Roisman - opisywał ich romans ${ }^{5}$. W drugiej, znanej nam dziś tragedii Eurypidesa, Hipolit uwieńczony, nie tylko nie ma aluzji do jakiegokolwiek romansu między nimi, ale też autor nie wprowadził bezpośredniego spotkania Hipolita z Fedra na scenie - to Piastunka wyznaje młodzieńcowi, że macocha jest w nim zakochana. Zabieg ten niektórzy uczeni uważają za reakcję poety na niezadowolenie ateńskiej publiczności, w której erotyka pokazywana w teatrze budziła niechęć. Seneka, wolny od ateńskiej konwencji

${ }^{4}$ Najobszerniejsza zachowana wersja mitu znajduje się w tragedii Eurypidesa Hipolit uwieńczony. Krótkie wzmianki znajdujemy u Pauzaniasza (Perieg. 2.27.4), Owidiusza (Fasti 6.735) oraz Pseudo-Hyginusa (Fab. 251).

${ }^{5}$ Zob. H.M. Roisman, The Veiled Hippolytus and Phaedra, "Hermes" 1999, nr 127, s. $397-409$. 
tragicznej i być może w ogóle nieplanujący wystawiania swoich dramatów ${ }^{6}$, nie tylko swobodnie przedstawia spotkanie Hipolita z Fedra, ale nasyca je seksualnymi podtekstami, a kulminacyjnym momentem spotkania jest próba przebicia Fedry mieczem przez młodzieńca. Ponieważ jednak kobieta wydaje się właśnie tego pragnąć, Hipolit ze wstrętem odrzuca broń i ucieka. Racine w swoim, siedemnastowiecznym, opracowaniu mitu wprowadza dodatkowo postać młodej Arycji, w której kocha się Hipolit, a sam młodzieniec pozbawiony jest tego wyraziście aroganckiego, zimnego charakteru, tak widocznego w antycznych tragediach, zwłaszcza zaś u Eurypidesa.

Z perspektywy psychoanalitycznej mit Hipolita wydaje się blisko powiązany z mitem Edypa. W pierwotnym, klasycznym ujęciu wczesnego Freuda ${ }^{7}$ istota kompleksu Edypa jest erotyczne pragnienie, jakie chłopiec odczuwa wobec matki, przy czym ojciec jest kochanym i zarazem nienawidzonym rywalem, posiadającym matkę na własność. Chłopiec nie tylko pragnie się pozbyć ojca, co w nieświadomości ulega zrównaniu z jego śmiercia, a więc $\mathrm{z}$ ojcobójstwem, ale ponadto obawia się, że ojciec, wiedząc o jego miłości do matki, z pewnością ukarze go kastracja, pozbawiając - na zasadzie prymitywnego prawa talionu - tego właśnie narządu, który był źródłem rozkosznych odczuć podczas fantazjowania o matce i który miał być narzędziem ewentualnego występku.

W późniejszych fazach ewolucji myśli Sigmunda Freuda kompleks Edypa zaczął się zbliżać do koncepcji opisującej ogół złożonych relacji z matką i ojcem, tworzących trójkątną konstelację, decydująca dla rozwoju osobowości i cywilizacji w ogóle ${ }^{8}$. To lęk kastracyjny powodować miał tak zwany „upadek kompleksu Edypa”, czyli fakt, że w normalnym rozwoju chłopiec ostatecznie rezygnuje ze zmysłowego aspektu miłości do matki, wypierając go i zastępując zmysłowość czułościąa. Jednocześnie, wyparta wrogość

${ }^{6}$ Kwestia, czy dramaty Seneki były pisane z myślą o wystawieniu i w ogóle wystawiane, czy też przeznaczone tylko do odczytywania, jest trudna do rozstrzygnięcia. Jednym ze znanych zwolenników tezy o niescenicznym przeznaczeniu Senecjańskich tragedii był, jeszcze przed wojna, T.S. Eliot (zob. T.S. Eliot, Seneca in Elizabethan translation, [w:] T.S. Eliot, Selected Essays, London 1966, s. 68).

${ }^{7}$ Zob. między innymi S. Freud, Objaśnianie marzeń sennych, [w:] tegoż, Dzieła, t. I, przeł. R. Reszke, Warszawa 2007, s. 228-236.

${ }^{8}$ Tenże, Totem i tabu, [w:] tegoż, Dzieła, t. IV: Pisma społeczne, przeł. R. Reszke, Warszawa 2009, s. 327-375; tenże, 'Ja' $i$ 'to', [w:] tegoż, Dzieła, t. VIII: Psychologia nieświadomości, przeł. R. Reszke, Warszawa 2009, s. 235-244 oraz tenże, Kilka psychicznych skutków anatomicznej różnicy płci, [w:] tegoż, Dzieła, t. V: Życie seksualne, przeł. R. Reszke, Warszawa 2009, s. 230.

${ }^{9}$ Przy klasycznym, wąskim rozumieniu wyparcia u zdrowej jednostki kompleks Edypa nie ulega wyparciu, ale „zniesieniu” czy „zniszczeniu”, gdyż samo wyparcie oznaczałoby, że osoba wciąż pozostaje pod patogennym wpływem emocji do obiektów kompleksu (S. Freud, Upadek kompleksu Edypa, [w:] tegoż, Dzieta, t. V..., s. 222-224). W przypadku zdrowego roz- 
wobec ojca zostaje zastapiona miłościa, a zmysłowość ulega odrzuceniu, podobnie jak w relacji do matki, czego finałem jest identyfikacja z ojcem jako wzorcem męskości. Identyfikacja związana jest zaś z akceptacja prawa ojca, czyli z przyjęciem podwójnego tabu kazirodztwa i ojcobójstwa. $\mathrm{Na}$ miejscu reprezentacji namiętnych, zmysłowych i ambiwalentnych relacji z obojgiem rodziców w psychice pojawia się instancja superego, odrębna od ego i id, którą Freud nazywa dziedzicem kompleksu Edypa, powstałym na skutek identyfikacji, głównie z obiektem ojcowskim.

Rozwój myśli Freuda w latach dwudziestych i trzydziestych oraz dalszy rozwój psychoanalizy w latach czterdziestych i pięćdziesiątych w coraz większym stopniu uwzględniał rolę fazy „preedypalnej” ${ }^{10} \mathrm{w}$ kształtowaniu się kompleksu Edypa, przy czym charakterystyczne dla preedypalności jest istnienie diady poprzedzającej trójkąt edypalny, w której to diadzie jedynym obiektem miłości i nienawiści jest dla dziecka matka. W wyniku potężnych mechanizmów projekcyjnych obraz preedypalnej matki jest przeniknięty agresją o charakterze oralnym i analnym. Ten obraz „straszliwej” czy też „okrutnej” matki pojawiał się już w refleksjach Karla Abrahama nad wczesną, oralną fazą rozwoju libido i związaną z nią melancholią ${ }^{11}$, a wcześniej jeszcze w erudycyjnych badaniach Carla Gustava Junga nad mitologia i religia ${ }^{12}$; później archetyp matki systematycznie studiowany był przez ucznia Junga, Ericha Neumanna ${ }^{13}$. Antropologiczne studia nad matriarchatem, zainspirowane klasyczną pracą Johanna Bachofena ${ }^{14}$, dostarczały

woju, jak sugeruje Otto Fenichel, mamy do czynienia nie tyle z wyparciem, co z sublimacja (por. O. Fenichel, The Psychoanalytic Theory of Neurosis, New York 1995, s. 140-151). Już jednak Fenichel wskazywał, że nawet u zupełnie zdrowych dorosłych kompleks Edypa nie znika całkowicie, ale wciąż pozostaje w nieświadomości, wyraża się w snach i może zostać ponownie ożywiony (s. 108). Obecnie pojęcie wyparcia ewoluuje w kierunku uznania go za mechanizm raczej zdrowy i dojrzały, czego przykładem jest koncepcja Ottona F. Kernberga (zob. np. tenże, Object-relations Theory and Clinical Psychoanalysis, New York 1976, s. 43-46), toteż używam tu również pojęcia wyparcia kompleksu bez zakładania patogennego charakteru tego zjawiska.

${ }^{10}$ Pojęcie to, które w drugiej połowie XX wieku miało zrobić zawrotną karierę w psychoanalizie, pojawia się w przywoływanym już eseju Kilka psychicznych skutków anatomicznej różnicy ptci (s. 229).

${ }^{11}$ Por. artykuł Abrahama na temat symboliki pająa (The Spider as a dream symbol, [w:] K. Abraham, Selected Papers, przeł. D. Bryan, A. Strachey, London 1927, s. 326-332) oraz jeden z ostatnich jego tekstów poświęconych wczesnemu rozwojowi libido (A Short study of the development of the libido, viewed in the light of mental disorders, [w:] K. Abraham, Selected Papers..., s. 418-470).

${ }^{12}$ C.J. Jung, Symbole przemiany: analiza preludium do schizofrenii, przeł. R. Reszke, Warszawa 1998.

${ }^{13}$ E. Neumann, Wielka Matka. Fenomenologia kobiecości, ksztattowanie nieświadomości, Warszawa 2008, s. 156-157.

${ }^{14}$ J.J. Bachofen, Matriarchat. Studium na temat ginajkokracji świata starożytnego podtug natury religijnej i prawnej, przeł. R. Reszke, Warszawa, 2007. 
zarówno klasycznym analitykom, jak i przedstawicielom szkoły jungowskiej, obszernego materiału potwierdzającego, że wyidealizowany obraz matki jako opiekunki darzącej dziecko wyłącznie miłościa, stanowi jedynie jeden z aspektów archaicznej matki, podczas gdy równie znaczący jest przerażający obraz matki wrogiej i prześladowczej. Sam Freud w eseju o Leonardo da Vincim wspomina egipską boginię-matkę Nut, przedstawianą jako sęp, związaną blisko ze śmiercią i rozkładem ${ }^{15}$.

Neumann z kolei pisze:

A mimo że świat, życie, naturę i duszę ujmowano również jako rodzącą i karmiąca, ochraniająca i ogrzewająca kobiecość, przeżywano je także w aspekcie przeciwnym jako śmierć i otchłań, niebezpieczeństwo i biedę, głód i nieporadność, jako chwilę, w której bezbronny człowiek wydany jest na łaskę i niełaskę okrutnej matki. Łono ziemi staje się zatem rozrywająca paszczą świata podziemnego; obok domagające się zapłodnienia łona i chroniącej jaskini ziemi czy góry pojawia się kłapiąca otchłań, ciemna dziura, pożerające łono grobu i śmierci, ciemność i nicość. Albowiem ta sama kobieta, która rodzi z ziemi życie i wszystko, co żywe, jest zarazem istota, która wszystko pożera i pochłania, która ściga swe ofiary, łapie je na pętlę, zarzuca na nie sieci ${ }^{16}$.

W świetle rozwoju psychoanalitycznej wiedzy pojawia się zatem pytanie, jak chłopiec może kochać matkę edypalną romantyczną miłością skoro wcześniej istniała w nim tak silna ambiwalencja wobec niej i opisane przez Melanie Klein zjawisko rozszczepienia matki na idealną i prześladowcza, ilustrowane w baśniowym i mitycznym dualizmie matki i macochy ${ }^{17}$. Okazało się, że wejście w klasyczny kompleks Edypa musi być poprzedzone przepracowaniem tej silnie ambiwalentnej, pełnej wrogości relacji z archaiczną matką, tak by jej obraz stał się bardziej złożony i stonowany, a agresja została zneutralizowana przez miłość. Jeśli się to nie udaje, dziecko w ogóle nie osiaga struktury osobowości zróżnicowanej na ego, id i superego ${ }^{18}$. Nawet zniwelowanie rozszczepienia jednak nie powoduje, że znika ambiwalencja wobec edypalnej matki, która jest kochana i nienawidzona - podobnie jak ojciec.

${ }^{15}$ S. Freud, Leonarda da Vinci wspomnienie z dzieciństwa, [w:] tegoż, Dzieła, t. X: Sztuki plastyczne i literatura, przeł. R. Reszke, Warszawa 2009, s. 87-106.

${ }^{16}$ E. Neumann, dz. cyt., s. 156-157.

${ }^{17}$ Zob. klasyczny esej: M. Klein, Uwagi na temat niektórych mechanizmów schizoidalnych, [w:] tejże, Zawiść i wdzięczność, Pisma, t. III, przeł. A. Czownicka, H. Grzegołowska-Klarkowska, Gdańsk 2007, s. 1-16. Rozumienie dualizmu matka/macocha w terminach preedypalnego rozszczepienia dominuje w szkołach zainspirowanych myślą Melanie Klein. Dla porównania, w swoim eseju o baśniach Bruno Bettelheim interpretuje - odwrotnie - postać złej macochy jako wrogi aspekt matki edypalnej, podczas gdy wyidealizowana, zmarłą matkę lub dobrą wróżkę - jako utracony, idealny aspekt matki preedypalnej (B. Bettelheim, Cudowne i pożyteczne. O znaczeniach i wartościach baśni, przeł. D. Danek, Warszawa 2010, s. 184-191).

${ }^{18} \mathrm{Na}$ ten temat zob. O.F. Kernberg, dz. cyt., s. 19-79. 
Richard Caldwell, filolog klasyczny stosujący psychoanalityczne metody interpretacji, omawiając mit Edypa, kładzie nacisk na aspekt ambiwalentnej relacji syna do matki właśnie. Wskazał on, że w mitach częstokroć to postać kobieca w konstelacji edypalnej budzi lęk czy wręcz wydaje się „kastrować” bohatera, i zadał pytanie: „czy edypalne lęki i obawy chłopca mogą skupiać się w równym lub większym nawet stopniu wokół postaci matki niż postaci ojca?”19. Caldwell pokazuje, że zarówno te wersje motywu „żony Putyfara”, w których młodzieniec jest pasierbem postaci kobiecej (Hipolit), jak i te, w których nie jest z nią spowinowacony, ale przebywa w gościnie (Bellerofont, Józef), mają w istocie charakter edypalny, gdyż dotyczą relacji chłopca do dwojga postaci rodzicielskich - figury ojcowskiej i macierzyńskiej ${ }^{20}$.

Caldwell powiada, że w mitach tego typu młodzieniec nie ma jeszcze atrybutów bohatera w momencie jego spotkania z matką (będę dalej tym terminem określał macierzyńska postać występująca w strukturze tego mitu) - zwłaszcza widać to w opowieściach o Bellerofoncie i Józefie, ale w pewnym stopniu także i o Hipolicie. Dopiero po oskarżeniu przez matkę młodzieniec podejmuje pewne aktywności, które sprawiaja, że staje się w pełni mężczyzna. W micie Bellerofonta oznacza to pokonanie żeńskiego potwora - Chimery. Amerykański badacz sugeruje, że głównym motywem mitu jest „wrogość postaci macierzyńskiej, której seksualne żądania nie zostaja zaspokojone" ${ }^{21}$. To żądanie seksualnego zaspokojenia, adresowane przez matkę do dziecka, rodzi wcześniejszy od lęku kastracyjnego lęk „związany z niezdolnością do zaspokojenia matki, zwłaszcza w rezultacie porównania własnych rozmiarów dziecka z rozmiarami matki i ojca". Jest to lęk przed własna „nieadekwatnością i niższością (swego rodzaju 'trema')”22.

Użycie określenia „trema” (ang. performance anxiety) wydaje mi się niezbyt fortunne do określenia tego potężnego lęku, który, wedle samego Caldwella, jest silniejszy niż lęk kastracyjny. Caldwell nie przywołuje tutaj rozwiniętej kilka dekad wcześniej teorii francuskiego analityka Beli Grunbergera, który szczegółowiej analizuje tego typu lęk, choć nie wiąże go wprost z mitami wspomnianymi przez amerykańskiego filologa. Warto więc potraktować rozważania Grunbergera jako uzupełnienie refleksji Caldwella. Grunberger twierdził, że w tym, co nazywa „wczesna pozycją edypalna”” ${ }^{23}$, chłopiec pragnie posiaśś matkę, lecz to pragnienie nie odnosi się to jeszcze do rywalizacji z ojcem. Jest ono bowiem związane nie z miłością obiektu, lecz

${ }^{19}$ R. Caldwell, The psychoanalytic interpretation of Greek myth, [w:] Approaches to Greek Myth, ed. L. Edmunds, Baltimore-London 2014, s. 343-392.

${ }^{20}$ Tamże, s. 364.

${ }^{21}$ Tamże, s. 365.

${ }_{22}^{2}$ Tamże.

${ }^{23}$ B. Grunberger, Narcissism: Psychoanalytic Essays, New York 1979, s. 269. 
z narcyzmem, który dla francuskiego analityka stanowi odrębną instancję psychiczna, rozwijającą się własnym torem. Grunberger nawiązuje do idei Sándora Ferencziego, który twierdził, że heteroseksualny stosunek genitalny symbolizuje powrót do łona matki, czyli pragnienie przywrócenia najbardziej pierwotnej ludzkiej błogości, utraconego raju ${ }^{24}$. Grunberger rozwija tę myśl, wskazując, że z łonem matki związany jest właśnie stan doskonałego zaspokojenia potrzeb narcystycznych, poczucie wszechmocy i doskonałości, w którym obiekt jest niepotrzebny, gdyż całym światem jest ,ja”. Po utracie tego stanu narcyzm dziecka dąży do przywrócenia go, a stosunek genitalny z matką staje się nośnikiem tego dążenia w fantazjach chłopca.

Problem jednak polega na tym, że zaspokojenie tej fantazji przez kilkuletniego chłopca jest całkowicie niewykonalne ze względu na rozmiary jego penisa. Próba realizacji tego pragnienia skończyłaby się katastrofą dla narcyzmu - co więcej, wyobrażone wejście w rolę ojca, który penetruje waginę matki, już jest dla dziecka narcystyczną raną, gdyż nieuchronnie chłopiec przeczuwa, że nie byłby w stanie zaspokoić matki i widzi przepaść między swoją znikoma, bezpłodną seksualnością a potężna, płodna genitalnościa ojca. W takim kontekście zakaz współżycia z matka, ustanowiony przez zazdrosnego edypalnego ojca, nie tyle jest trauma, co wybawieniem. Grunberger pisze, że chłopiec „,chciałby zastapić narcystyczną traumę (wynikająca z jego immanentnej impotencji) jakimś zewnętrznym zakazem, który byłby nieskończenie mniej bolesny dla jego narcyzmu" ${ }^{25}$. Prawo ojca ingerujące w diadę matka-dziecko zamienia narcystyczny uraz (,nie potrafię posiaść matki, bo jestem za mały”) w klasycznie edypalną fantazję (,ojciec zabrania mi posiaśś matkę"), które generuje wprawdzie nienawiść do ojca i lęk przed kastracja, ale pozwala na rozwijanie miłości do matki i - przede wszystkim - chroni narcyzm chłopca.

Żona Grunbergera, Janine Chasseguet-Smirgel, również wybitna analityczka, rozwinęła na tej podstawie koncepcję, w myśl której chłopiec ma do dyspozycji dwa rozwiązania, stojąc na symbolicznym rozdrożu między losem Narcyza i losem Edypa (odniesieniem do tych dwóch mitów posługiwał się również sam Grunberger). Może wybrać drogę Narcyza, czyli „drogę na skróty”, w wyniku czego dążyć będzie do natychmiastowego zaspokojenia narcyzmu i uniknięcia traumy, a wtedy rozwija się w kierunku perwersyjnym. Polega to na odrzuceniu z pogarda genitalności ojca, czyli odrzuceniu rzeczywistości i fundamentalnej dla cywilizacji podwójnej różnicy między płciami i pokoleniami, oraz na idealizacji własnej infantylnej seksualności, za sprawą fantazji, że matce to wystarczy. Jeśli matka podsyca te fantazje,

\footnotetext{
${ }^{24}$ S. Ferenczi, Thalassa: a Theory of Genitality, London 1989.

${ }^{25}$ B. Grunberger, dz. cyt., s. 269.
} 
sugerując, że ojciec jest niemęski, a chłopiec może ją zaspokoić jako jej „mały mężczyzna", utrwala się struktura perwersyjna. Uniemożliwia ona chłopcu umieszczenie w ojcu ideału ego i identyfikację z nim, powodując, że dziecko musi nieustannie odpierać zarówno lęk kastracyjny, jak i bronić swego narcyzmu przed traumatycznym zranieniem. Druga droga, która pójść może chłopiec na tym etapie rozwoju, droga Edypa, polega na akceptacji bolesnej niemożliwości zaspokojenia matki i własnej niższości w porównaniu z ojcem, z nadzieja, że po długim czasie chłopiec dorośnie i stanie się równy ojcu. Wymaga to akceptacji czasu i historii, rezygnacji z natychmiastowego zaspokojenia oraz zakłada tolerowanie własnego poczucia niższości ${ }^{26}$.

Wracając do Caldwella, możemy rozwinąć jego koncepcję lęku przed własną niższością seksualna, który wydaje się manifestować w motywie „żony Putyfara”, w kierunku badanych przez Grunberga i Chasseguet-Smirgel losów dziecięcego narcyzmu i konfliktu mitu Narcyza z mitem Edypa. Oto jak Caldwell opisuje obronny mechanizm obecny w mitach z motywem „żony Putyfara”:

seksualne potrzeby i pragnienia [matki], wyobrażone przez edypalnego syna, sa tak przytłaczające i przerażające, że musi on zaprzeczyć własnym pragnieniom i projektować je na matkę: to nie ja jej pragnę, to ona pragnie mnie. Ale ojciec zawsze wierzy w kłamliwe oskarżenia żony, a powodem tego jest fakt, że nie sa one właściwie kłamliwe. Syn naprawdę pożąda matki (choć nie może się do tego przyznać), jest naprawdę winny i dlatego musi zostać ukarany ${ }^{27}$.

Mity Bellerofonta i Józefa opisują sukces bohatera w pokonaniu lęku przed matka, co zakończone zostaje również akceptacją ze strony ojca i identyfikacją z nim. Mit Hipolita zaś opisuje porażkę, eksponuje lęk kastracyjny i przedstawia typowo edypalną karę wymierzona przez ojca synowi, który przekroczył prawo, ale pierwotną przyczyną kastracji jest tutaj matka, która mówi ojcu o pragnieniach syna. Caldwell rozumie Chimerę jako obraz przerażającej seksualnie matki, podobnie interpretuje też postać Sfingi z mitu Edypa - wskazuje na to, że potwór ten i Jokasta strukturalnie stanowią w micie obronna „dekompozycję" obrazu matki na aspekt przerażający i upragniony. Edyp zdobywa bowiem Jokastę, jako obiekt swego pragnienia, po tym, jak pokonuje Sfingę. Ponadto obydwie postacie w micie popełniaja samobójstwo, co zbliża je do siebie, zwłaszcza że, jak Caldwell trafnie zwraca uwagę, samobójstwo Sfingi jest niezrozumiałe (skrzydlaty potwór rzuca się w przepaść) i wydaje się efektem „naddeterminacji” strukturalnej ${ }^{28}$.

\footnotetext{
${ }^{26}$ J. Chasseguet-Smirgel, Creativity and Perversion, New York 1984, s. 27-29.

${ }^{27}$ R. Caldwell, dz. cyt., s. 366.

${ }^{28}$ Tamże, s. 372.
} 
Można dodać, że jest to również obraz zawierający wątki preedypalnej Straszliwej Matki, skondensowane z obrazem edypalnego obiektu, co tylko wzmacnia lęk. Interpretację Caldwella potwierdza szereg innych dowodów zaczerpniętych z literatury i ikonografii. Materiał antropologiczny wskazuje na związki Sfingi z innymi manifestacjami archetypu okrutnej matki ${ }^{29}$. W ikonografii potwór ma nagie piersi i przedstawiany jest z Edypem niemal jak para obejmujących się kochanków. Pożarcie przez Sfingę można więc rozumieć jako seksualne pochłonięcie, destrukcyjny akt seksualny. Warto również zwrócić uwagę, w jaki sposób Sfinga pokazana została w Fenicjankach Eurypidesa ${ }^{30}$. Poeta podkreśla tam, że lubowała się w porywaniu młodych chłopców i za każdym razem nazywa ją córą Ziemi i dziewica, co również zbliża ją do archetypu Wielkiej Matki (Matka-Ziemia, Dziewica Matka) ${ }^{31}$.

Związek mitu Hipolita z mitem Edypa wydaje się więc z perspektywy psychoanalitycznej ewidentny. Niemniej jednak nawet poza tą perspektywą łączy je zasadniczy wątek, jakim jest erotyczne pragnienie młodzieńca skierowane do starszej kobiety, do matki. Roisman zasugerowała - a interpretacja ta jest dobrze udokumentowana i spójna - że niezachowany Hipolit zakrywajacy twarz wydawał się zawierać opis romansu Hipolita i Fedry, a na pewno opis jego pożądania, choćby dlatego, że w literaturze epoki klasycznej zasłonięcie twarzy wiązało się zawsze ze wstydem z powodu popełnionego występku - gdyby to tylko Fedra pożądała Hipolita, nie miałby on powodu do zakrywania twarzy ${ }^{32}$. Ponadto, trudno byłoby uzasadnić fakt, że Ajschylos, przemawiając w Żabach Arystofanesa, krytykuje Eurypidesa za to, że przedstawiał Stheneboję i Fedrę jako pornai (nierządnice) ${ }^{33}$, gdyby ich jedynym grzechem była z trudem wyznana młodzieńcowi miłość. Autorka ta w podobnym duchu interpretuje też samooślepienie Edypa, tym samym wskazując na daleko idącą analogię między tymi dwoma bohaterami.

\section{Królowa Śniegu i Sfinga}

Początek powieści Madame przedstawia tytułową bohaterkę w sposób, który nie wydaje się sugerować wprost wymiaru edypalnego, gdyż dyrektorka i nauczycielka francuskiego nie jest nawet macochą bohatera, nie

\footnotetext{
${ }^{29}$ Zob. E. Neumann, dz. cyt., s. 45 i 243.

${ }^{30}$ Eurypides, Phoeniss. 806-811 i 1018-1042.

${ }^{31}$ Pisze o tym dość obszernie Jung (Symbole przemiany..., s. 228-238).

${ }^{32}$ Roisman przywołuje choćby zasłonięcie twarzy przez głównego bohatera w Heraklesie oszalałym Eurypidesa czy przez Sokratesa w Platońskim Fajdrosie (H.M. Roisman, dz. cyt., s. 407-409).

${ }^{33}$ Arystofanes, Batrach. 1043.
} 
mówiąc już o byciu matka, przez co kazirodczy wymiar tej relacji nie jest od razu widoczny. Niemniej jednak status macierzyński Madame rozwijany jest na przestrzeni powieści, głównie poprzez porównywanie relacji chłopca z nauczycielką do konfliktu obecnego w Fedrze Racine’a. Wcześniej jednak funkcję tę pełni różnica wieku - Madame ma trzydzieści parę lat, a chłopiec - osiemnaście, toteż mogłaby ona być jego matka. Oprócz wieku istotny jest też fakt, iż jest ona dyrektorką szkoły, ma więc nad bohaterem władzę. W tym aspekcie Libera wprowadza wątki, których brak w klasycznych opracowaniach mitu - symboliczna matka czy macocha nie jest tu bowiem słaba, zakochana i bezradna, jak u Eurypidesa czy Seneki, ale potężna, chłodna i wyniosła. Te cechy zbliżają ją raczej do Chimery czy Sfingi - groźnych postaci macierzyńskich, znajdujacych się w kontraście do słabej zazwyczaj Fedry. Libera pisze: „Trzymała się prosto, miała nienaganne maniery, a przy tym ciągnał od niej jakiś mrożący chłód. Piękna i zimna, wspaniała i nieprzystępna, dumna i bezlitosna - istna Królowa Śniegu”34.

Libera poprzez aluzję do Królowej Śniegu Andersena odsyła czytelnika do postaci małego Kaja, żyjącego z Królową w quasi-małżeńskim związku, z którego wydobyła go dopiero, mocą swej miłości, Gerda, dziewczynka w jego wieku. Zarówno u Andersena, jak i w postaci Madame obecny jest więc, choć zamaskowany, motyw kazirodczego przywiązania chłopca do niedostępnej, chłodnej i dominującej matki. Kontrast między zimną Madame a Fedra $\mathrm{z}$ trzech wspomnianych tragedii sięga jednak jeszcze głębiej. Tam jest ona bowiem gorąca i namiętna - u Seneki, na przykład, podkreśla to metaforyka ognia, która pojawia się wielokrotnie ${ }^{35}$ - toteż o Fedrze można powiedzieć wszystko, lecz nie to, że jest Królową Śniegu. Co ciekawe, w tragediach to Hipolit właśnie jest zimny, niedostępny i surowy ${ }^{36}$, podczas gdy Libera przedstawia swojego bohatera jako rozpalonego namiętnością młodzieńca.

Ponieważ Madame jest groźna i budzi lęk w uczniach oraz w bohaterze, nosi na sobie piętno „groźnej Afrodyty” z antycznych tragedii, czyli bogini reprezentującej sadystyczną matkę preedypalną oraz, zarazem, edypalna, seksualnie wymagająca matkę ${ }^{37}$. Libera zresztą nie ukrywa bynajmniej powiązania Madame z antycznymi boginiami, pisząc, że uczniowie spostrzegali ja jako „boginię, co jakimś cudem zstapiła z Olimpu na ziemię”. Dalej czytamy:

pięknej pani dyrektor nie przestano wielbić, tyle że miłość do niej przybrała szczególną formę. Z jednej więc strony, po cichu, modlono się do niej żarliwie, darując jej

${ }^{34}$ A. Libera, Madame, Kraków 2010, s. 44. Strony podaję zawsze według tego wydania.

${ }^{35}$ Por. Seneka, Phaed. 102-103, 131, 187-193, 280, 291-293, 330-331, 337, 640-644.

${ }^{36}$ Seneka porównuje go do twardego kamienia: Phaed. 582.

${ }^{37}$ Eurypides w prologu do tragedii wkłada Afrodycie w usta te słowa: „gdy czczą pokornie moją moc, wywyższam,/ miażdżę, gdy zaczną się wobec nas pysznić” (Hipp. 5-6; przeł. J. Łanowski). 
okrucieństwo i puszczając w niepamięć wszelkie upokorzenia, z drugiej, tym razem na głos - na boku, po katach, w klozecie - pastwiono się nad nią straszliwie, nurzając ją bezlitośnie w bagnie karczemnych plotek i niewybrednych fantazji. (s. 45)

U Eurypidesa pojawiają się dwie boginie - adorowana, czysta Artemida i pogardzana, obrażana przez Hipolita, seksualna Afrodyta. Podobne rozszczepienie widać w powieści Libery, gdzie uczniowie z jednej strony modla się do Madame, a z drugiej poniżają ją w klozecie ${ }^{38}$.

Libera przedstawia też zabawny wątek ciekawości uczniów dotyczącej życia seksualnego Madame (s. 46-47). Powstają w szkole trzy „,szkoły teoretyczne”, które mają wyjaśnić, co oznacza, że Madame jest jakoby „frygida”" (s. 51-52). Pierwszy pogląd głosił, że Madame pozbawiona jest narządów rozrodczych, jej układ moczowo-płciowy ogranicza się do cewki moczowej. W myśl poglądu drugiego frygida to kobieta „nierozbudzona i zahamowana uczuciowo". Wreszcie trzecia szkoła, mająca wzięcie tylko wśród dziewcząt, głosiła, że Madame brzydziła się mężczyznami, wielbiła jedynie samą siebie i ze sobą cieleśnie obcowała, co polegać miało, między innymi, na wielogodzinnych kapielach, namaszczaniu się kremami i chodzeniu nago po mieszkaniu.

Te fantazje przypominają dziecięce teorie seksualne, o których pisał Freud $^{39}$, a które podkreślaja przepaść między dojrzała, genitalną seksualnością rodziców, a „polimorficznie perwersyjna” seksualnością dzieci, blisko związana z narcyzmem, autoerotyzmem, urynacją i defekacja. Uczniowie zastanawiają się też, czy Madame ma jakiegoś mężczyznę, a jeśli ma, to jak go traktuje lub jeśli już nie ma - z jakiego powodu go porzuciła. Przy tej okazji pojawia się sugestia, że porzuciła ona mężczyznę ze względu na jego niewystarczającą męskość, słabość czy impotencję, co sugeruje wspomniany na wstępie obraz groźnej, kastrującej matki oraz narcystycznej rany chłopca, który czuje, że nie jest w stanie jej seksualnie zadowolić (s. 47). Ten narcystyczny watek rozwijany jest także wprost w opisie skrajnego poczucia niższości doświadczanego przez chłopców: „O chłopcach zaś nie ma co mówić. Pryszczaci, z meszkiem wczesnego zarostu na twarzach, o niewyrobionych głosach i nieopanowanych ruchach - byli w jej obecności skazani na mękę wstydu, mogli przeżywać jedynie piekło upokorzenia" (s. 51). Widać tutaj zarazem fascynację macierzyńską seksualnością jak i ogromny przed nią lęk ${ }^{40}$.

${ }^{38}$ Wątki analnej erotyki, które się tu pojawiaja, Freud wiąże z popędem zawładnięcia i z wyobrażeniem matki dominującej i kontrolującej. Por. np. S. Freud, Trzy rozprawy z teorii seksualnej, [w:] tegoż, Dzieła, t. V..., s. 88-89 oraz tenże, Popędy i ich losy, [w:] tegoż, Dzieła, t. VIII..., s. $74-75$.

${ }^{39}$ Tenże, O dziecięcych teoriach seksualnych, [w:] tegoż, Dzieła, t. V..., s. 153-165.

${ }^{40}$ Watki analne, a zwłaszcza sadyzm i dominacja, obecne są też w dosyć rozbudowanym motywie Popiołów Żeromskiego (s. 52-61) oraz ekranizacji tej powieści przez Wajdę, które opisane są przez pryzmat gwałtu. Uczniowie ekscytują się sceną z filmu, w której Pola Raksa 
Nie tylko jednak dominacja i zagrożenie zbliża postać Madame do postaci Sfingi, ale również wątek zagadki. Gdy bohater rozpoczyna swoje śledztwo i zaczyna się interesować prywatnym życiem nauczycielki, Madame jawi się jako Sfinga właśnie, zadająca poniekąd bohaterowi zagadkę, na którą usiłuje on odpowiedzieć. Chłopiec myśli, że chce przeniknąć tożsamość Madame, ale paradoksalnie dowiaduje się w ten sposób, kim sam jest, poznaje siebie. Jest to sytuacja przypominająca sytuację Edypa, który odpowiadając na zagadkę Sfingi, odpowiada jednocześnie na pytanie: „kim jestem?”. Nie tylko dlatego, że odpowiedź brzmi „człowiek” i nie tylko dlatego, że Edyp wraca właśnie ze świątyni Apollona w Delfach, która nawołuje: „poznaj siebie", ale także dlatego, że zagadka Sfingi zbudowana jest na liczbie nóg, którą można odczytać jako aluzję do tożsamości Edypa. W niektórych interpretacjach imię Oidipus nie tylko oznacza „obrzmiałą stopę”, ale łączyć też ma wiedzę (gr. oida - wiem) oraz stopę (gr. pus), która została przebita przez jego ojca. Tak czy inaczej, stopa wiąże się w nieświadomych skojarzeniach z penisem (co widać choćby w częstym występowaniu fetyszyzmu związanym ze stopami i butami) ${ }^{41}$, a jej obrzmiałość i przebicie (kastracja) wyraźnie wskazuja na seksualne aspekty przenikające nawet pozornie nieseksualne wątki mitu. Seksualność Edypa i jego pochodzenie (rodzice) wiążą się zatem, jak zagadka i wiedza ${ }^{42}$.

Śledztwo w sprawie Madame Libera również nasyca erotycznymi skojarzeniami, analogicznie do interpretacji Freuda, który uważał, że zagadka, którą Edyp rozwiązuje, jest zagadką seksualności (dla Claude’a Lévi-Straussa poniekąd również było to pytanie seksualne: „skąd się biorą dzieci?”"3). Autor przedstawia śledztwo jako próbę penetracji, czego zresztą specjalnie nie maskuje w warstwie językowej. Czytamy na przykład, że „Penetracja parteru w tym pionie nie przyniosła, niestety, żadnego rozstrzygnięcia..."

gwałcona jest przez „góralskich zbójników” (s. 52), symbolicznie wydających się reprezentować dzikiego, brutalnego ojca. Tylko tak zwierzęcy, męski ojciec jest zdolny do seksualnego posiadania matki (Madame), co powoduje, że chłopcy czują się tej możliwości pozbawieni. Są raczej świadkami tego, co Freud nazwał „sceną pierwotną”, czyli stosunku seksualnego rodziców, i to w sposób typowy, czyli stosunek ten przedstawiony jest jako przerażający i ekscytujący zarazem gwałt (S. Freud, $Z$ historii nerwicy dziecięcej, [w:] tegoż, Dzieła, t. VI: Dwie nerwice dziecięce, przeł. R. Reszke, Warszawa 2009, s. 127). Symboliczna dekompozycja obrazu ojca, jego rozpad na całą grupę rozbójników, podkreśla jeszcze brutalność tej sceny.

${ }^{41}$ Por. klasyczny artykuł Freuda interpretujaccy stopę i but jako symbole matczynego fallusa: S. Freud, Fetyszyzm, [w:] tegoż, Dzieła, t. VIII..., s. 305-309.

${ }^{42}$ Zob. na ten temat: P. Pucci, Oedipus and the Fabrication of the Father: Oedipus Tyrannus in Modern Criticism and Philosophy, Baltimore 1992, s. 67-71 oraz L. Edmunds, Freud and the father: Oedipus complex and Oedipus myth, "Psychoanalysis and Contemporary Thought" 1985, nr 8, s. 93-94.

${ }^{43}$ C. Lévi-Strauss, Antropologia strukturalna, przeł. K. Pomian, Warszawa 2000, s. 185208. 
(s. 66). Na kilku stronach bohater próbuje poznać wnętrze domu, ogląda różne pokoje (s. 63-69). Motyw pokoju, pomieszczenia, wnętrza powtarza się tu obsesyjnie, sugerując aluzyjnie zainteresowanie tajemniczym wnętrzem ciała matki, jeśli odwołać się do klasycznego odczytywania przez psychoanalizę pojemników jako symboli kobiecych genitaliów. Sam bohater przedstawiony jako voyeur - odczuwa podniecenie, patrząc tylko, a nie wchodząc do środka (s. 67), co stanowi indywidualne dopełnienie zbiorowego, analnego voyeuryzmu uczniów, którzy w scenerii klozetu fantazjują o gwałcie na Poli Raksie/Madame.

\section{Panna i Wodnik}

Motywy mityczne ulegają interesującym przekształceniom w rozdziale zatytułowanym „Pieśń Wodnika i Panny”. Jest to wypracowanie napisane na francuski, w którym bohater pisze:

Następnie przypomnijmy, czego symbolem jest woda. Woda w różnych kulturach jest nieodmiennie symbolem źródła lub prapoczątku. Jest to materia prima. Na przykład, w tradycji indyjskiej, w wodzie tkwi Jajo Kosmiczne, a w hebrajskim Genezis, u zarania wszystkiego, właśnie ponad wodami unosi się Boży Duch. Dlatego też woda jest zawsze łączona z pierwiastkiem żeńskim, z płodnością z ciemna głębia, z życiodajna potęga. I rzeczywiście, czyż życie nie zalęgło się w wodzie? Czyż nie wypełzło na ląd z ciemnego łona mórz? A zatem gwiezdny Wodnik, choć ma postać mężczyzny, reprezentuje w istocie to, co w naturze kobiece. Poi, aby ożywić. Czuwa nad dziełem życia. A przy tym - pluskiem wody - przyzywa, wabi i kusi. (s. 85-86; podkreślenia autora powieści)

Mamy tu kilka motywów, które obecne sa już w antycznych tragediach o Hipolicie. Zarówno u Eurypidesa, jak i Seneki Fedra skojarzona jest z Afrodyta (narodzona z morza) oraz z samym morzem, które jest zarazem życiodajne i groźne, wydające z siebie życie i pochłaniające, rodzące i uśmiercające. To Seneka zwłaszcza posługuje się obrazem wody do zilustrowania namiętności Fedry, która wymyka się wszelkiej kontroli. Tym bardziej uderzający jest fakt, że Hipolita spotyka ostatecznie śmierć wyłaniająca się z morza. Seneka sugeruje, że straszliwy byk, który z niego wychodzi, niejako rodzi się z wody - w tekście czytamy bowiem, że morze jest potworem „ciężarne" ${ }^{44}$. Rozwierająca się przed Hipolitem czeluść symbolizuje więc grozę macierzyńskiej seksualności, która przynosi życie wraz ze śmiercią. Rozszarpanie, które można interpretować jako symboliczną kastrację Hipolita, dokonywane jest u Eurypidesa i Seneki z woli matki, choć to Tezeusz i Po-

${ }^{44} \mathrm{~W}$ oryginale czytamy: nescioquid onerato sinul gravis unda portat (1019-1020), czyli „ociężała fala niesie coś w swym ciężarnym łonie”. 
sejdon występują jako pośrednicy - karzący ojcowie. Warto zwrócić uwagę, że sam Posejdon, który posyła potwora, jest starszym od Zeusa bóstwem, ściśle związanym $\mathrm{z}$ matriarchatem i na głębszym poziomie reprezentuje raczej siły macierzyńskie niż ojcowskie. Antoni Libera wykorzystuje ten archaiczny symbol morza jako łona matki, źródła życia i śmierci, i podkreśla te wątki, pisząc o płodności, ciemnej głębi i życiodajnej potędze wody. Mamy nawet „wypełzanie” życia z łona mórz, co odsyła do bykokształtnego potwora w antycznych tragediach.

Z kolei Panna, reprezentująca mitycznego Hipolita, z którym bohater się identyfikuje, „Trzyma w ręce pokaźne gęsie pióro” - jest to, oczywiście, motyw falliczny, ale Libera eksponuje tutaj także te cechy, które poeci przypisywali zawsze Hipolitowi, wyrzekającemu się miłości kobiet: „Dziewictwo, czystość, niewinność... Cechy te tylko z pozoru są właściwe kobiecie. W sferze idei dziewictwo jest atrybutem męskości. Kobiecość z istoty rzeczy nigdy nie jest dziewicza - jest zawsze wtajemniczona. Inicjacja to akt, który ma zawsze za soba." (s. 86; podkreślenia autora powieści). Choć bohater pisze tu o archetypach, opisywana przezeń sytuacja doskonale oddaje jedna zwłaszcza, modelową relację - matki i syna, gdzie matka jest już zawsze po inicjacji (skoro ma syna, to poznała współżycie z jego ojcem), a on zawsze przed inicjacja, zawsze dziewiczy, a zarazem nieustannie przyporządkowany do niej, do tej otchłani seksualności, która jest jego początkiem.

W konkluzji wypracowania bohater stwierdza, że Panna i Wodnik to

młodzieniec i dojrzała kobieta. On, zapatrzony w dal, niedoświadczony, niewinny, marzy, układa wiersze. Ona natomiast, wiedząca, świadoma tego, co ważne, przyzywa go pluskiem wody. „Chodź, tu jest źródło”, powiada, nie wymawiając słów, „przyjdź do mnie, to cię napoję, ugaszę twoje pragnienie”. (s. 86)

Warto zwrócić uwagę, jak w tym wypracowaniu prymitywna, analna erotyka, która wcześniej przenikała fantazje skupione na Madame (Królowa Śniegu i jej „układ moczowo-płciowy”, klozet, sadomasochizm, gwałt) przekształca się w bardziej dojrzałą rozwojowo erotykę edypalną, gdzie matka jawi się jako tajemnicza i pełna uroku, subtelnie przyzywa i kusi chłopca, w czym z pozoru zupełnie brak już wątków agresywnych.

Z pozoru - Libera bowiem posługuje się aluzją literacka, by zasugerować czytelnikowi inną interpretację. Wskazówką jest wspomniana en passant ballada Erlkönig Goethego. W utworze tym, który ukazany jest jako podobny do mitu „Panny i Wodnika”, nic już nie znajdujemy z natchnionych obrazów czystej miłości Panny do niedostępnego, subtelnie przyzywającego Wodnika. Napotykamy w nim raczej narastający od początku nastrój grozy i mroku. Zwłaszcza straszliwa postać Króla Olch, który ma kobieco-męską naturę i pragnie uwieść chłopca, jest perwersyjna, hermafrodytyczna i pedofilna 
zarazem. Jeśli uznać to odwołanie do Erlkönig za wskazówkę interpretacyjna, odsłaniającą zniekształcające operacje bohatera powieści, można by powiedzieć, że dla Libery pod wzniosła, romantyczną adoracją bogini przez zakochanego młodzieńca kryje się prymitywna perwersyjność, zawsze gotowa niespodzianie wybuchnać.

Kiedy zestawimy ze sobą te dwa poziomy, możemy zauważyć, że ujawnia się tutaj pewna sekwencja, w której przerażająca fantazja o uwodzącej matce zastapiona jest tęsknota za obiektem nieosiagalnym, bo zakazanym, dokładnie tak, jak to opisał Grunberger. Bohater powieści wznosi obronę przed perwersyjna seksualnością za pomocą natchnionego eseju, w którym postać Madame przedstawia w radykalnie inny sposób niż na początku powieści, a same uczucia chłopca zostają niejako „oczyszczone” z perwersyjnej seksualności. Interesujący jest też zabieg polegający na odwróceniu płci - Panna reprezentuje chłopca, a Wodnik - matkę. Można tu jednak dostrzec charakterystyczne dla fazy analnej prymitywne zrównanie męskości z aktywnością i dominacja, a kobiecości z pasywnością i uległością. Bohater odwraca tutaj role - Panna dzięki gęsiemu pióru uzyskuje męskość, podczas gdy Wodnik staje się kobieco pasywny jako adorowana, receptywna otchłań macierzyńskiego ciała. Sfinga zastapiona zostaje więc Jokasta, Straszliwa Matka - matka romantycznie ukochaną i niedostępna, a impotentny chłopczyk - młodym, fallicznym mężczyzną ${ }^{45}$. Pomimo to w tekście współistnieja i współgraja ze sobą te dwa wymiary, a ten bardziej zagrażający nieustannie grozi przebiciem się przez warstwę obronną i zawładnięciem narracją bohatera.

\section{Ojciec wchodzi na scenę}

Jeśli przyjmiemy, że Madame jest symboliczną matką bohatera, ciekawe staje się to, jak przestawiona jest w powieści jego realna matka. Albo raczej to, jak nie jest ona przedstawiona. Matka bohatera ma charakter niemal widma, jest zasadniczo nieobecna, niewidzialna, pozbawiona charakterystycznych cech - ojciec zaś jako osobny rodzic nie pojawia się w ogóle. Ilekroć opisana jest interakcja bohatera z matka, ona jest surowa i krytyczna,

${ }^{45}$ Por. interpretację Szczuki (K. Szczuka, dz. cyt., s. 99), która twierdzi, że mamy tu do czynienia z „płynnościa” płci. Autorka nie próbuje jednak pokazać różnych funkcji, jakie z perspektywy psychodynamicznej może odgrywać przyjmowanie identyfikacji męskich i żeńskich, a jedynie wydaje się sugerować, że zamazane zostają czy zakwestionowane granice między płciami, czemu nie towarzyszą żadne hipotezy, po co miałyby one być w ogóle zamazywane. Na przykład koncept „matki fallicznej” lub negatywnego kompleksu Edypa z pasywno-receptywnym nastawieniem chłopca wskazywać mogą na ścieżki interpretacyjne, z których Szczuka nie korzysta, zadowalając się konkluzja, że płeć jest płynna i nieustabilizowana. 
zwykle dlatego, że jej syn błąka się do późna poza domem. Jego błąkanie się wynika z pożądania Madame, o czym matka nie wie, ale ponieważ edypalnym matkom dana jest moc czytania w myślach swych synów, bohater i tak ma poczucie winy, jakby oddawał się występnemu procederowi za jej wiedza.

Libera przedstawia uderzający kontrast urzekającej, pachnącej perfumami Chanel, wyrafinowanej i podniecającej Madame z jednej strony oraz surowej, cierpkiej matki bohatera $\mathrm{z}$ drugiej. Wygląda to niemal tak, jakby pustkę po matce zajęła nauczycielka, jakby tylko Madame mogła reprezentować kazirodczą fantazję dorastającego chłopca. W powieści Libery bohater symbolicznie wciąż „wychodzi z domu”, przemieszczając swoje konflikty na obiekty pozarodzinne, takie jak Madame, ale również - jak przyjaciel rodziców, pan Konstanty i jego syn, Jerzyk, którzy Madame znaja i w pewnej mierze pomagaja bohaterowi w jego poszukiwaniach. Obronna zamiana pożądania w agresję u Racine'a wyrażona jest wprost, gdyż tam Fedra broni się przed pożądaniem udawaną niechęcią i w pełni zdaje sobie sprawę z tego, jak i przed czym się broni. To samo o wiele skuteczniej jednak i całkowicie nieświadomie robi bohater powieści, który broni się przed uczuciem do matki, przemieszczając pożądanie na Madame, a kreując obraz mało pociagającej, uszczypliwej rodzicielki. Bohater, co ciekawe, unika wszelkich bliższych spotkań z matką - raz słyszy jej głos z drugiego pokoju, a kiedy indziej staje ona w drzwiach, gdy chwilę rozmawiaja, ale nie wchodzi do jego pokoju. Ten brak między nimi, ten dystans, jest symbolicznie komplementarny do intensywności relacji chłopca z Madame.

Klasyczna, trójkątna konstelacja edypalna pojawia się, gdy Libera wprowadza do powieści ojca-rywala, uzupełniając początkowy, diadyczny obraz relacji z Madame. Edypalny ojciec pojawia się w powieści na dwa sposoby. Jeden sposób można by, używając terminologii Lacana, odnieść do porządku wyobrażeniowego, a drugi - do symbolicznego ${ }^{46}$. Po pierwsze, rywalami

${ }^{46}$ Jeśli chodzi o teorię Lacana, to oprócz angielskiego wydania Écrits (J. Lacan, Écrits. A Selection, transl. B. Fink, New York-London 2002) warto polecić bardzo klarowną prezentację Pawła Dybla (Urwane ścieżki. Przybyszewski - Freud - Lacan, Kraków 2000, s. 209-280), która przezwycięża to, co Whitebook nazwał "Lacan's obstinate, narcissistic, and self-serving obscurantism" (J. Whitebook, Perversion and Utopia: Study in Psychoanalysis and Critical Theory, Cambridge 1995, s. 188). Zob. również przejrzyste podsumowanie najważniejszych idei Lacana w: S. Turkle, Psychoanalytic Politics: Freud's French Revolution, New York 1978, s. 50-59). W kwestii Lacanowskiej koncepcji funkcji ojcowskiej cenne są rozważania brytyjskiego psychoanalityka Fakhry Davidsa, który próbuje umiejscowić niejasne idee Lacana w kontekście innych szkół psychoanalizy (M. Fakhry Davids, Father in the internal world. From boy to man to father, [w:] The Importance of Fathers. A Psychoanalytic Re-evaluation, eds. J. Trowell, A. Etchegoyen New York 2002, s. 66-92; polskie wydanie: Po co sq ojcowie? Rozważania psychoanalityczne, przeł. Danuta Golec, Lech Kalita, Marta Kruszyńska-Mąka, Warszawa 2015). 
bohatera są konkretne postacie mężczyzn, głównie przedstawione jako karzące, surowe i autorytarne, które stają między chłopcem a nauczycielką. Taka funkcję pełni, na przykład, kontroler biletów w tramwaju, w scenie, w której młodzieniec jedzie na spotkanie do ambasady, podróżując od jednej atrakcyjnej i tajemniczej kobiety do drugiej (s. 227-230). Cała ta scena stanowi, jak się wydaje, aluzję do sceny, w której Hipolit - za sprawą ojca wypada $\mathrm{z}$ rydwanu i ginie ciagnięty przez własne konie. Libera zastępuje wóz tramwajem (który jest zresztą nazywany w tej scenie „wozem”), a kontroler prowokuje pasażerów do buntu i oporu. W kulminacyjnym momencie chłopiec wypada z tramwaju, próbując uciec, a efekty stanowią ironiczne przekształcenie losu Hipolita:

dźwigając się z bruku odkryłem z przerażeniem rozmiary spustoszenia, jakie w moim ubraniu poczynił był upadek. Rękawy i przód kurtki były poobcierane i poznaczone błotem, szew pod pachą - pęknięty, a prawa nogawka spodni - rozdarta, i to paskudnie: na samym przodzie, pośrodku, zwisał trójkątny strzęp, odsłaniając kolano. „Jak ja się teraz pokażę mademoiselle Legris?”. (s. 230)

W klasycznych tragediach to ciało Hipolita rozdarte zostało na strzępy przez spłoszone konie - szczególnie Seneka podkreśla ten aspekt, w makabrycznej scenie, w której Tezeusz próbuje poskładać rozszarpane zwłoki syna $\mathrm{z}$ ledwie rozpoznawalnych szczątków ${ }^{47}$. Tutaj podarte zostaje jedynie ubranie bohatera, podczas gdy jemu samemu nic poważnego się nie dzieje, co daje efekt swoistej ironicznej ulgi, że kara ojca za miłość do Madame-Matki nie okazuje się tak straszna. Niemniej jednak, Libera podkreśla narcystyczny aspekt tego Hipolitowego upadku, na który zwracał uwagę Grunberger bohater powieści ubolewa bowiem, że pani Legris zobaczy go w tym stanie i że nie zrobi na niej odpowiednio dobrego wrażenia. Roił sobie wcześniej, że uwiedzie ją chłopięcym urokiem, jak to uczynił z kobietą pracująca w bibliotece. Rozerwanie ubrania stanowi więc kastrację w miniaturze, kastrację niegroźna, zabawna, ale zarazem Libera przemyca aluzję do niedojrzałości i niższości seksualnej chłopca, do jego braku doświadczenia w konfrontacji z kobieta, która prawdopodobnie będzie wolała jakiegoś „porządnego” mężczyznę, a nie obdartego podrostka.

Druga postać ojcowska pojawia się już po wizycie u panny Legris - jest to milicjant, który legitymuje chłopca (s. 240-243). Ponownie pojawia się tu poczucie zagrożenia, a postać męska, reprezentująca autorytet i prawo, ingeruje w fantazje chłopca związane z Madame (które przemieszczone sa również na dwie wspomniane kobiety). Libera po mistrzowsku stwarza atmosferę wiszącego nad chłopcem zagrożenia, niejasnego, niedopowiedzianego, ale wyraźnie sugerującego, że to, co „robi z Madame” (śledztwo,

${ }^{47}$ Seneka, Phaedr. 1262-1271. 
marzenia) jest występne i może spotkać się z karą. Ponadto na przestrzeni całej powieści pojawiają się również inne groźne, zakazujące i karzące figury ojcowskie, takie jak obdarzeni znaczącymi nazwiskami czy pseudonimami wicedyrektor Soliter lub nauczyciel Eunuch.

Po drugie, ojciec pojawia się w powieści na zasadzie Lacanowskiego ojca symbolicznego, nom/non-du-pêre, prawa ojca czy ojcowskiego „nie”. Dla Lacana jest to przede wszystkim język jako rządzona zasadami struktura, która przekracza wszechmocne fantazje dziecka, umieszcza go przemoca w sferze kultury i czyni człowiekiem. Dla francuskiego psychoanalityka kastracja sprowadza się w gruncie rzeczy do faktu, że wyrażenie w języku tego, co niejęzykowe, odbywa się za cenę utraty tego, czego nie można wypowiedzieć. Lacan identyfikuje symbolicznego ojca z wszystkim, co ogranicza, zakazuje, odbiera, choć zarazem - co umożliwia wyjście poza relację z matka.

W tym kontekście francuscy ideolodzy rewolucji obyczajowej lat sześćdziesiątych i siedemdziesiątych, celebrujący bunt przeciw autorytetowi, uważali całą kulturę, język sam w sobie oraz logiczne myślenie za opresyjny system, od którego trzeba się emancypować lub zniszczyć go poprzez rewolucyjna przemoc ${ }^{48}$. Leszek Kołakowski zwraca uwagę na charakterystyczne dla protestów 1968 roku postulaty zniszczenia państwa i kultury oraz „wyzwolenia studentów od opresji zdawania egzaminów i uczenia się” 49 . Podkreśla także utopijność tego ruchu, którą w kontekście analitycznym można rozumieć jako pragnienie powrotu do błogości połączenia $\mathrm{z}$ archaiczna, idealną matka, czemu przeszkadza ojciec reprezentujący prawo i zasadę rzeczywistości: „rozpaczliwe pragnienie cudu, wiara, że istnieje jeden

${ }^{48}$ Zob. pracę Sheryl Turkle, autorki umiarkowanie sympatyzującej z ideami lewicowymi, która klarownie pokazuje, w jaki sposób koncepcje Lacana były wykorzystywane politycznie w latach sześćdziesiątych i siedemdziesiątych (S. Turkle, dz. cyt., s. 60-86). Por. także krytykę pewnych idei politycznych wyrastających z myśli Lacana w cytowanej już pracy Whitebooka (Perversion and Utopia, s. 121-132). Leszek Kołakowski pisze: „Żadne godne uwagi wyniki intelektualne nie powstały do tej pory w tej sferze ideologicznej. [...] Ideologiczne fantazje leftystów nie były niczym więcej niż farsą albo kaprysami rozpieszczonych dzieci klas średnich, jeśli ekstremistyczne grupy w tym ruchu do złudzenia przypominały bojówki faszystowskie, to cały ruch z pewnością był objawem głębszego załamania się wartości, którymi żyły społeczeństwa demokratyczne przez wiele dziesięcioleci” (L. Kołakowski, Główne nurty marksizmu, Poznań 2001, s. 572-574). Warto nadmienić, że trzeci tom Gtównych nurtów nigdy się nie ukazał we Francji, w wyniku niesformalizowanej cenzury dominujących tam środowisk intelektualnych. O tej swego rodzaju cenzurze wspomina pod koniec życia również Pierre Hadot. Francuski historyk filozofii przytacza fakt, iż praca Erica D. Hirscha Validity in Interpretation (New Haven 1967) również nie mogła zostać wydana we Francji i komentuje, pół żartem, pół serio, że nie tylko w Rzymie istnieje indeks ksiag zakazanych (P. Hadot, The Present Alone is Our Happiness. Conversations with Jeannie Carlier and Arnold I. Davidson, przeł. M. Djaballah, Stanford 2009, s. 62).

${ }^{49}$ L. Kołakowski, dz. cyt., s. 573. 
magiczny klucz, który za jednym zamachem otworzy drzwi raju [...] wiara, że można za jednym zamachem przeobrazić kompletnie świat i uczynić zeń boską krainę cudów, czemu przeszkadzają tylko wielkie monopole i profesorowie uniwersytetów"50.

W powieści Libery to nie zachodnia, chrześcijańska kultura jest systemem opresji, ale tyrania komunistycznego reżimu. To właśnie PRL reprezentuje agresywny aspekt edypalnego ojca, który przemocą więzi Madame i odbiera bohaterowi radość i realizację pragnień, a wspomniane postacie kontrolera czy milicjanta stanowią reprezentacje tego ojca na poziomie wyobrażeniowym. Z drugiej strony, zachodnia kultura w powieści jest idealizowana i kontrastowana $\mathrm{z}$ PRL-em, pełniąc funkcję dobrego ojca, ideału ego, z którym w normalnym rozwoju chłopiec się identyfikuje, stając się przez to mężczyzna. Dlatego nie tylko PRL rości sobie prawa do Madame, Zachód również ja „posiada”, gdyż tam się urodziła i wychowała. Bohater nie jest jednak o to zazdrosny i nie żywi wrogości do kultury zachodniej. Wręcz przeciwnie, pragnie kontaktu z nią i z nią się identyfikuje. Tak jak w rozwoju chłopca decyzja o wyparciu agresji i identyfikacji z ojcem oznacza „teraz nie mogę mieć matki, ale jeśli kiedyś stanę się takim mężczyzną jak ojciec, to znajdę kobietę taką jak matka", tak w powieści decyzja o wyborze kultury zachodniej i odrzuceniu komunizmu może być wyrażona jako „teraz nie mogę mieć Madame, której pragnę, ale jeśli poznam zachodnią kulturę, którą ona kocha, to zasłużę na jej miłość i zdobędę ją".

\section{Powrót wypartego: Hipolit i Fedra}

W miarę rozwoju powieściowej akcji Libera wprowadza coraz wyraźniej wątek seksualny, który na początku istnieje tylko w aluzjach. Można to określić psychoanalitycznym terminem „powrót wypartego”, gdyż następuje osłabienie mechanizmu zastosowanego w eseju o Pannie i Wodniku uwznioślone uczucie miało zastapić nagą żądzę, ale ten zabieg się nie udaje. Najpierw mamy do czynienia z szeregiem aluzji wskazujących na seksualne aspekty relacji bohatera z Madame. Na przykład prosi ona bohatera o przyniesienie klucza, a kiedy wchodzi on do jej gabinetu, widzi otwartą torebkę (s. 247-248). Budzi się w nim pragnienie „spenetrowania” tej torebki, podobnie jak kiedyśs - jej mieszkania, by poznać sekrety nauczycielki. W tej scenie niejako matka prowokuje syna do incestu, zaprasza go do wejścia w „zaklęte rewiry”, ale on powściaga się, powstrzymuje, licząc na większą nagrodę w dalszej perspektywie. Co zresztą okazuje się strategią słuszna.

${ }^{50}$ Tamże, s. 574-575. 
Dopiero obecność bohatera na jakoby pornograficznej wystawie Picassa stanowi moment, w którym uświadamia on sobie seksualny aspekt swych uczuć do Madame i konfrontuje się z własną niedojrzałością seksualna, dojrzałością Madame i lękiem przed seksem. Wewnętrzny głos bohatera (jego superego?), mówi mu: „marzysz o jakiejś wiktorii. - Na czym ma ona polegać, jeśli wolno zapytać? Na tym, że spojrzy na ciebie? Że powie ci coś miłego?... W istocie chodzi o to, abyśs się z nią połączył i oddał jej nasienie” (s. 258). Ojciec edypalny drwi tutaj z bohatera, sugerując, że nie jest on w stanie zaspokoić Madame z racji swojej niedojrzałości, genitalnej niższości. Widać to też w kontraście do postaci francuskiego Dyrektora, z którym Madame wydaje się mieć romans - tak jak kontroler, milicjant i partyjni nauczyciele sa reprezentantami komunistycznego ucisku, tak Dyrektor ucieleśnia kulturę Zachodu. Jest mężczyzną o wiele bardziej męskim i atrakcyjnym dla Madame niż bohater.

Sztuka jawi się w tej scenie jako obrona przed potęga, straszliwą potęga kobiecej seksualności: „A pamiętaj, mój mały, że to zaledwie obrazki - sztuka, kreacja, ironia. W życiu rzecz jest o wiele... nieporównanie mocniejsza i mniej cywilizowana. Dzika, gwałtowna, obłędna. Deliryczna, pijana" (s. 258). To „mały” podkreśla falliczną niższość bohatera, narcystyczny uraz, który groziłby mu, gdyby miał zrealizować swe zakazane pragnienia. Co więcej, pornograficzne wizje Picassa nie „czynią zadość” pragnieniom chłopca. „W dziedzinie słodkiej ułudy zaspokojenia nie ma. Bo co? Bo nie ma formy, w której by mogło się ziścić" (s. 259). Przez tę formę, w kontekście powyższych rozważań, rozumiem formę genitalnego współżycia, do którego chłopiec nie czuje się zdolny.

Pojawia się także wątek z Czarodziejskiej góry Tomasza Manna, czyli zderzenie romantycznej miłości z biologią i fizjologią ciała ${ }^{51}$, tyle że u Manna zderzenie to nie ma formy narcystycznego urazu, jak tu:

No, a teraz wybieraj! Wolisz mnie taka, jak widzisz, elegancko ubrana, w postawie wyprostowanej, zniewalająca spojrzeniem, a zwłaszcza giętka mową? Czy obnażoną do cna, leżąca i rozwaloną w nieprzystojnej pozycji i, miast czarować słowami, wyjacca jak zwierzę w rui? Chcesz wspinać się ze mną? Iść w Alpy? Wejść na Mont

${ }^{51}$ Por. między innymi refleksje Hansa przy okazji lektury podręczników biologii w rozdziale „Dociekania” (T. Mann, Czarodziejska góra, przeł. J. Kramsztyk, Wrocław 1995, t. I, s. 510-531) oraz ostatnie zdania jego wielkiego miłosnego wyznania, wygłoszonego - co nie bez znaczenia dla Libery! - po francusku podczas balu z okazji Nocy Walpurgi, gdzie mówi on do Kławdii Chauchat (przytaczam w przekładzie): „Tak, na Boga, pozwól mi wchłaniać woń skóry pod twoimi kolanami, gdzie kunsztowna torebka stawowa wydziela swą śliską maź! Pozwól, by usta moje dotknęły ze czcią na przedniej części uda twej Arteria femoralis, która dzieli się niżej na dwie tętnice goleni. Pozwól mi upajać się wyziewami twoich porów i dotykać twego meszku, istoto ludzka z wody i białka, której przeznaczeniem jest anatomia grobu, i pozwól mi zginąć z ustami na twoich ustach!” (s. 633-634). 
Blanc - szczyt ludzki? Czy stoczyć się w Rów Mariański? W prawieczna głębię i mrok? W matecznik pierwotniaków? (s. 261; podkreślenia autora powieści)

W tym wyobrażonym dialogu na pewien czas osłabione zostaja obrony i chłopiec konfrontuje się w fantazji z zagrażającą seksualnością Madame nie tylko jest ona zwierzęciem w rui, rozkraczonym w nieprzyzwoitej pozycji; bynajmniej nie prowadzi go na szczyt dziewiczego natchnienia (Panna), ale ściaga w głębię i mrok. Co więcej - „matecznik” podkreśla tu aluzyjnie wątek relacji z matka, który jest tu nieustannie obecny. W tym momencie, dopiero po odsłonięciu zarówno żądzy chłopca, jak i zagrażającego obrazu matki-Madame, Libera wprowadza wprost mit Hipolita, poświęcając cały rozdział opisowi przestawienia, na którym jest zarówno Madame, jak i jej uczeń, a które - niczym Senecjańska tragedia czy teatr w teatrze w Szekspirowskim Hamlecie - stanowi komentarz do fabuły ukryty w jej wnętrzu.

Bohater, relacjonując swoje przeżycia ze spektaklu, dokonuje interpretacji tragedii Racine'a, która to interpretacja w niemal psychoanalitycznym duchu eksponuje seksualne wątki mitu. Gdy Fedra mówi do Hipolita, że tylko on może jej zapewnić bezpieczeństwo, bohater komentuje: „Już ta kwestia pobrzmiewa niejaką dwuznacznością (,zostań jego obrońcą”, więcjakby moim mężem?). Ale to jeszcze nic. Fedra rozpędza się i traci panowanie nad potokiem wymowy. Zaczyna utożsamiać pasierba z jego ojcem" (s. 272). Wątek ten jest o wiele bardziej jednoznacznie rozwinięty w scenie konfrontacji Hipolita i Fedry, która zostaje nazwana „baletową z racji wymownej gestyki aktorów.

Na brzmiącym wieloznacznie, ostatnim, króciutkim „daj”, Fedra stojąca na scenie na lewo od Hipolita (z punktu widzenia widowni) sięgała prawą ręką po jego krótki miecz, przytroczony rzemieniem do pasa na lewym boku. Na to Hipolit - też prawą - kierował ku rękojeści, chcąc wzbronić do niej przystępu. Wtedy zaś Fedra lewa - chwytała to prawe ramię - od góry, powyżej nadgarstka - i odciagała ku sobie; natomiast prawa, powoli, wydobywała miecz i unosiła go w górę.

W tej pozycji, zwrócenie trois quarts ku widowni, zastygali w bezruchu na dobrych kilka sekund.

Był to wspaniały obraz - mieniący się znaczeniami. Kiść ręki Hipolita zwisała w uchwycie Fedry jak głowa martwego ptaka. Kontrastował z nią miecz wzniesiony ostrzem do góry. Mierzyli się spojrzeniami. Wszystko to miało coś w sobie z perwersji i masochizmu: prowokowanie gwałtem do popełnienia gwałtu. [Fedra jakby mówiła:] „przynajmniej rusz ręka, zrób coś z tą wiotka garścia, bezwolna, niegodną mężczyzny, która mnie upokarza i poniża do reszty. Przynajmniej ją obróć i weź... weź mnie... na chwilę... za rękę!" (s. 273-274)

Interpretacja jest o tyle interesująca, że odsyła do wypracowania o Pannie i Wodniku, gdzie nie tylko miało miejsce odwrócenie płci, ale cała namiętność ulokowana została w chłopcu, podczas gdy starsza kobieta je- 
dynie kusiła i wzywała go do zanurzenia się w jej otchłannych wodach. Wskazywałem wówczas na to, że aluzja do Króla Olch sugerowała, iż pod wzniosłym obrazem Panny i Wodnika kryje się perwersyjny obraz uwodzącej czy wręcz gwałcącej matki. Teraz, gdy Libera pozwala na powrót wypartego, macierzyńska postać w fantazji chłopca już nie tylko subtelnie kusi i uwodzi, ale wprost zmierza do gwałtu, gdy Fedra, chwytając rękę Hipolita, w istocie, jak sugeruje autor, chwyta symbolicznie jego penisa. Jej aktywna, seksualna moc budzi lęk przed narcystycznym zranieniem: chłopiec okazuje się bowiem impotentem wobec starszej kobiety, nie jest w stanie jej zaspokoić swoim niedojrzałym penisem, który symbolicznie przemieszczony został na jego dłoń, tę „wiotka garść, bezwolną, niegodna mężczyzny”, jak pisze Libera.

Bohater, oglądając przedstawienie, jest przekonany, że to Fedra jest upokorzona i poniżona w tej scenie, wydaje się jednak, że o wiele bardziej poniżony jest Hipolit, który, w porównaniu do ojca, nie jest zdolny do zaspokojenia kobiety. Jest on tutaj pasywny i zdominowany przez Fedrę. Taka edypalna wykładnia tej sceny możliwa jest wewnątrz powieści dopiero po wystawie Picassa, która obnaża to, co ukryte za obronami zaprezentowanymi w wypracowaniu o Pannie i Wodniku. Wyparte powraca więc, wstrząsając psychiczną spójnością młodzieńca. Konkluduje on bowiem:

krucha jest w człowieku powłoka jego szlachectwa. Wystarcza oto podrażnić nienasyconą wolę i wtrącić do wrzącej krwi szczyptę soli z piołunem, by puścił natychmiast kręgosłup i kościec sublimacji, dojrzewajace przez lata czy nawet pokolenia - te wszystkie nawyki i formy szlifujace nature - i aby z wyniosłej damy wyszła bezwstydna hetera, czy nawet jeszcze gorzej: z królowej - goniąca się suka. (s. 276-277)

Bohater, którego zawiodły mechanizmy obronne, konfrontuje się wprost z pożądaniem Madame (czego wprost nie czyni żaden z trzech słynnych Hipolitów klasycznej i klasycystycznej tragedii, którzy przypisują namiętność Fedrze). Musi stawić czoła nie tyle groźnemu ojcu-rywalowi, co samej Madame, która nie jest już skryta za fasadą lodowatej wyniosłości i francuskiego wyrafinowania, ale zaczyna przerażać swoją potęga, nie tylko oralnie pożerająca, analnie torturująca, ale też edypalnie zagrażającą doświadczeniem ostatecznej impotencji i wynikającej stąd narcystycznej traumy.

W tym punkcie bohater snuje fantazje, które mają wpisać jego życie w matrycę mitu o Hipolicie i Fedrze, dokonując jego wykładni:

I oto w tym ostępie - ponurym i zatęchłym - na krótko przed terminem odzyskania wolności, w ciżbie nieokrzesanych, niemrawych podopiecznych napotyka młodzieńca o szczególnych zdolnościach, manierach i wymowie, i równie nieprzeciętnym uroku osobistym. [...] przyjaznych uczuć nie okazuje mu jednak, przeciwnie, gra - jak Fedra - odpychającą władczynię. (s. 278) 
Także w młodzieńcu budzi się żądza:

niezwykły uczeń nie tylko po prostu jest czarującym młodzieńcem; zdaje się ponadto cicho ją adorować. [...] Uwielbia jac. Ubóstwia! Stawia ją na ołtarzu! Choć tyle ma wokół siebie zalotnych rówieśniczek. To pochlebia ambicji. To osobliwie podnieca. To wyzwala pragnienie, aby mu wyjść naprzeciw i stać się dlań, zaprawdę, wszechmogącą boginia.

Nie można jednak ulec tego rodzaju pokusie. To byłoby ryzykowne i - niegodziwe zarazem. Wszelako, z drugiej strony, nic nie zrobić w tej sprawie, dalej grać lodowata, nieczułą Królową Śniegu - to też nie rozwiązanie. (s. 278-279; podkreślenia autora powieści)

Warto zwrócić uwagę na typowo edypalny motyw narcystyczny, czyli poczucie wyjątkowości chłopca - w trójkącie edypalnym ta wyjątkowość ma oznaczać przewyższenie ojca, którym matka jest mniej zainteresowana i który w ogóle jest z pozoru szary, nudny i mniej atrakcyjny niż uroczy książę, za którego ma się chłopiec. Narcyzm jednak obecny jest w bohaterze niejako niezależnie od edypalności, wcześniej już - w jego koncentracji na sobie i przekonaniu o własnym geniuszu, o własnej mocy twórczej i zdolności wywierania wpływu na wydarzenia.

W tym punkcie jednak pojawia się Dyrektor jako edypalny rywal, który odbiera bohaterowi Madame (s. 280-281). Bohater voyeurystycznie ich śledzi i staje się świadkiem traumatycznej „sceny pierwotnej”, w której Dyrektor (reprezentujący francuski polot i wspaniałość Zachodu) pokonuje chłopca, będąc atrakcyjniejszy dla Madame niż niedorostek o wygórowanych ambicjach (s. 303-307). Niemniej jednak pobrzmiewa tu echo Grunbergerowskiej idei, że jest to w istocie rzeczy wybawienie: bohater nie musi sprawdzać, czy okazałby się dla Madame obiektem dość interesującym seksualnie i czy potrafiłby zaspokoić jej pragnienia, może o tym do woli fantazjować, wyobrażając sobie własną męską moc, ale trauma impotencji jest mu oszczędzona i zamieniona w poczucie bycia pokonanym przez ojca, który ustanawia tabu i zabrania dostępu do matki. Niejako tytułem komentarza do tej sceny pojawia się znowu realna matka bohatera - krytyczna, surowa, stoi w drzwiach, wymieniając z synem kilka oschłych zdań.

Pojawienie się ojca, broniącego dostępu do matki, ratuje bohatera od narcystycznego urazu, a to wybawienie zostaje w bardzo interesujący sposób przedstawione jako kastracja. Podczas „prac ręcznych” (umieszczenie ich w cudzysłowie dodatkowo sugeruje znaczenia masturbacyjne, szczególnie w kontekście sceny pierwotnej, jaką bohater obejrzał, a w istocie nie obejrzał jej, ale skazany był na zazdrosne fantazjowanie o niej), chłopiec rani się w palec. Opisane to jest z zatrzymującą uwagę detalicznością: „I właśnie wskutek tego trafiło mnie wreszcie w rękę, którą trzymałem konar; dokładniej: w dolną część wskazującego palca" (s. 324). Detaliczność tego typu sugeruje 
obecność zniekształcającej pracy cenzury, o której pisał Freud - kłamstwa zwykle obfitują w szczegóły, których brak realnym wspomnieniom, a we śnie mniej istotne szczegóły ulegają wyeksponowaniu. Bohater jakby mówił: „nic nie grozi mojemu penisowi, zraniłem się przecież w dolnq część wskazującego palca". Przecinanie potężnego konara, zbyt grubego, by można go było przepiłować, w tym kontekście przywołuje na myśl odwetowe pragnienie kastracji na Dyrektorze, który zmusił chłopca do bolesnego oglądania jego współżycia z Madame, przypominając bohaterowi jego genitalną niższość. Zreszta odwetowa fantazja kastracyjna pojawiła się już zaraz po scenie pierwotnej, gdy wychodzący od Madame dyrektor porównany jest do wymiętoszonego Antka, który wcześniej stanowił symboliczny ekwiwalent „Zwiędłego” penisa.

Autokastracja bohatera przy próbie wykastrowania rywala nie tylko nie kończy relacji z Madame, ale wprowadza ją na nowy poziom. Oto autokastracja staje się pretekstem, ba, sposobem na takie zbliżenie się do dyrektorki, o jakim bohater mógł dotąd jedynie marzyć. Madame zajmuje się bowiem nim, niczym pielęgniarka, opatrując mu palec. „No, pokaż, coś tam zmajstrował - powiedziała figlarnie - $\mathrm{z}$ tym nieszczęsnym paluszkiem. Da się go uratować, czy nic tylko amputacja?" (s. 327). Tutaj pojawia się znowu zabawa nie tylko wątkiem niedojrzałości chłopca (już nie „dolna część wskazującego palca”, ale „nieszczęsny paluszek”), ale też wątkiem kastracji, która żartobliwie grozi mu Madame.

Scena nabiera więc wyraźnie masochistycznego charakteru, co obecne było już podczas interpretacji spektaklu. Madame mówi: „To teraz się przekonamy, czy jesteś mężczyzna, czy nie - sięgnęła po flakonik. - Uprzedzam, będzie bolało! - I zaczęła na przemian spryskiwać i przecierać kawałkiem waty ranę" (s. 328). Bohater nie pozostawia sobie ani czytelnikowi złudzeń co do seksualnej treści tej sadomasochistycznej sceny:

Dla mojej świadomości, skażonej literaturą i skłonnej do mitomanii, była to sytuacja na granicy perwersji. Krew, wata, uścisk dłoni i zadawanie bólu, lecz dla mojego dobra, a przy tym bez współczucia, bez rozczulania się, przeciwnie, jakby z uciechą i dziwną ciekawością - to wszystko miało posmak najwystępniejszej przygody. Hańbiła mnie, gwałciła, wystawiała na próbę moje opanowanie i zdawała się czerpać z tego jakaśs przyjemność, a w każdym razie jak gdyby ekscytowało ją to. (s. 328)

\section{Rozwiązanie konfliktu: sublimacja}

Kulminacyjna scena, w której chłopiec jest opatrywany przez Madame, stanowi jednak nie tylko wtargnięcie popędu w kruchy porządek psychiki bohatera. Stanowi ona też punkt zwrotny, w którym pojawia się rozwiązanie 
konfliktu, zarysowane już w eseju o Pannie i Wodniku, ale tutaj staje się bardziej skuteczne. Młodzieniec komentuje tę sytuację niemalże językiem Freuda:

Bez fundamentu kultury, bez tabu i obyczaju, a zwłaszcza bez języka, bez mowy kunsztownie wiązanej, Hipolit byłby samcem, w którym budzi się żądza, a Fedra... goniąca się suka. A tak ma pani.... Boga i stwarzanego Adama w stylu Michała Anioła lub wzniosłą alegorię ludzkiego niespełnienia... (s. 336)

Wcześniej, podczas wystawy Picassa, mowa była w podobnym tonie o tym, jak krucha jest kultura, pod którą kryją się bynajmniej nieucywilizowane popędy.

Freud nie tylko w swojej dojrzałej koncepcji kultury z końca lat dwudziestych, ale już w daleko wcześniejszych pracach nieustannie podkreślał, że cena za stworzenie kultury jest wyrzeczenie się popędu ${ }^{52}$. Twórca psychoanalizy uważał, że wyzwolenie popędów oznacza barbaryzację i upadek wielkich osiagnięć człowieka - sztuki, nauki, religii itd., podczas gdy ich wypieranie oznacza cierpienie i zagrożenie nerwica. Porównał tę sytuację do Scylli i Charybdy i do końca życia był przekonany, że nie ma żadnego rozwiązania tego dylematu, które byłoby dla człowieka satysfakcjonujące. Ludzka kondycja, według niego, oznacza cierpienie, wyrzeczenie i nieustanny lęk przed superego. Jedynym jaśniejszym punktem $\mathrm{w}$ tej pesymistycznej wizji jest wiara Freuda w to, że niektóre jednostki, należące do elity ludzkości, są zdolne wyrzec się popędów i nie zachorować od tego, lecz przekształcić energię popędową $\mathrm{w}$ procesie sublimacji ${ }^{53}$.

Powieść Antoniego Libery zawiera w sobie taką Freudowska, ale nacechowaną większym optymizmem wizję relacji popędu do kultury. Młodzieniec radzi sobie z traumatyczną sytuacja, w której Madame-Matka jako "goniąca się suka" zagraża mu zarówno narcystycznie, jak i przez odniesienie do prawa ojca, poprzez sublimację, symbolizację i substytucję obiektu. Słowo staje się narzędziem umożliwiającym wydostanie się z konfliktu Edypa czy też - Hipolita. Freud twierdził, że słowa zdolne są wchłonąć energię popędów i przekształcić ja, a tak zwany proces wtórny (myślenie zorganizowane przez logikę i rzeczywistość) stanowi warunek przeciwstawienia się pier-

${ }^{52} \mathrm{Na}$ temat Freudowskiej koncepcji kultury zob. Kulturowa moralność seksualna a wspótczesna nerwowość, Przyszłość pewnego złudzenia, Kultura jako źródto cierpień oraz Dlaczego wojna?, [w:] tegoż, Dzieta, t. IV..., a także Leonarda da Vinci wspomnienie z dzieciństwa (s. 98) oraz Mojżesz Michała Anioła (s. 184), [w:] tegoż, Dzieła, t. X...

${ }^{53}$ Jego następcy, jak Anna Freud czy Otto Fenichel, będą starali się o wiele pozytywniej spojrzeć na ludzki los, kładąc nacisk na sublimację i inne dojrzałe mechanizmy obronne, które umożliwiają stłumienie popędu bez płacenia za to ceny w postaci zubożenia osobowości czy symptomów chorobowych. Por. np. przełomową pracę Anny Freud - Ego i mechanizmy obronne, przeł. M. Ojrzyńska, Warszawa 2012, s. 22-53 - oraz wspomniane już, równie klasyczne rozważania Fenichela na temat sublimacji (O. Fenichel, dz. cyt., s. 141-167). 
wotnemu procesowi dominującemu w nieświadomości. W omawianej scenie chłopiec proponuje Madame, by przeczytali razem dialog Hipolita i Arycji oraz Hipolita i Fedry - ma to być sposób na wyrażenie ich przedświadomych i nieświadomych uczuć, a zarazem - jak każdy sen, dowcip lub neurotyczny symptom - sposobem na ukrycie ich przed wewnętrzną cenzura.

Propozycję chłopca autor zabawnie przedstawia jako obraz stworzenia Adama z fresku Michała Anioła. Nie jest to jednak tylko żart - chodzi tu rzeczywiście o akt stwórczy i sublimacyjny zarazem, o taką koncepcję sztuki, jak ta, którą znajduje się w pismach Freuda. Artysta nie zapada na nerwicę dzięki swemu talentowi - jego dzieło bowiem wyraża konflikt, ale zarazem uwalnia od niego poprzez symbolizację, będąc ekwiwalentem fantazjowania i dziecięcej zabawy. Bohater powieści proponuje Madame właśnie zabawę, psychodramę, fantazjowanie, ale przede wszystkim - tworzenie poprzez sublimację, gdy obsadza sam siebie w roli Fedry. Początkowo konfrontacja z wyobrażeniem Madame-Matki jako „goniącej się suki” jest zbyt dużym wyzwaniem dla chłopca, toteż sam przyjmuje rolę podmiotu seksualnego pożądania, jak to jest w obronnej identyfikacji, którą opisał Freud. To odwrócenie ról powoduje, że Madame jest młodzieńcza i dziewicza (Arycja lub Hipolit), a chłopiec identyfikuje się z dojrzała, seksualną kobieta. Nieświadoma biseksualność zostaje tu użyta - podobnie jak w wypracowaniu o Pannie i Wodniku - obronnie wobec bardziej zagrażających impulsów popędowych. Co więcej, Madame żartobliwie porównana jest do Ludwika XIV, słuchającego tragedii Racine'a. Ma ona w ten sposób reprezentować także superego, które siedzi i pilnuje, by między Madame a bohaterem nie zaszło zbyt wiele. Eksternalizacja superego uwalnia chłopca na czas „zabawy” od edypalnego poczucia winy.

W tej wspólnej fantazji dochodzi do zetknięcia, które jest powtórzeniem, ale i przekształceniem tego, co oglądali podczas spektaklu Fedry na scenie. Oto chłopiec chwyta rękę Madame, a ona „obróciła w imadle mej prawej, gorącej dłoni swą chłodna, szczupłą rękę i cofnęła ją nieco, tak aby spotkać się z moja, i uścisnęła ja, od dołu, silnym uściskiem” (s. 340). Z jednej strony, chłopiec wyrzeka się tutaj niejako penisa i przyjmuje rolę pasywno-kobieca, gdyż jego dłoń formuje gorący pierścień wokół szczupłej ręki Madame, która staje się niejako kobieta falliczna, penetrujacca go. Ta obronna formacja, w której chłopiec utożsamia się z kobieta, nie podoba się jednak Madame i wprowadza ona nowy watek - zaciska swoją dłoń na dłoni chłopca: wchodzi w rolę kobiety trzymającej penisa mężczyzny w uścisku.

To zetknięcie się, symbolizujące stosunek seksualny, budzi głos superego i groźbę kastracji: „Poszedłeś za daleko...”, znowu odezwał się głos, mój stary, dobry znajomy. „Posmakowałeś boskości... Dotknąłeś jej... Poznałeś... Cena tego jest jedna: chmura na Pańskim obliczu... wygnanie z Raju... padół" 
(s. 344). Niemniej jednak nic strasznego się nie dzieje. Kara edypalnego ojca nie spada na chłopca, oszczędzona mu też jest narcystyczna rana impotencji. Wydaje się, że sublimacja właśnie powoduje, że potencjalnie traumatyczna sytuacja przekształcona zostaje w coś twórczego i wyzwalającego. Zamiast katastrofy, chłopiec otrzymuje jeszcze jedną szansę kontaktu z Madame podczas tańca na studniówce, gdzie znowu pojawia się seksualna symbolika (s. 349-350). Dyrektorka jest dominująca i kpiąca, on niepewny swej wartości i potencji. Ale pomimo to wychodzi z sytuacji obronną ręka.

Ostatecznie, bohater traci Madame - nie dopuszcza go ona do swojego domu, a następnie wyjeżdża na Zachód, co symbolicznie oznacza, że posiadł ją mężczyzna (ojciec) o wiele lepszy od bohatera. Zachód i Francja to w końcu „Centre de civilisation”, jak głosi tytuł jednego z rozdziałów, a młodzieniec jest tylko obdarzonym talentem i bujną wyobraźnią maturzystą z komunistycznego kraju. Bohater przeżywa typowe rozwiązanie kompleksu Edypa - żałobę po utracie matki, akceptację własnej niższości wobec ojca, ale, jak wcześniej wskazywałem, jego obraz Zachodu pozostaje pozytywny. Choć Francja odbiera mu Madame, tak jak w realności Dyrektor, który miał z nia romans, chłopiec jest w stanie to zaakceptować i pokochać ten Zachód jako swój ideał ego, postanawiając, że kiedyś stanie się taki, by być godny Madame.

Narrator powieści pokazuje drogę, na której możliwe jest zrezygnowanie $\mathrm{z}$ tego, co w nas jest perwersyjne, kazirodcze i destrukcyjne, poprzez sublimacyjne przemieszczenie i symbolizację. Młodociany bohater, zmagający się ze swymi zwierzęcymi żądzami, nieustannie przemieszcza swoje pragnienie z Madame-Matki na rozmaite obiekty kultury, które sa z nią powiązane, skojarzone, ale zarazem na tyle od niej oddalone, że nie budzą lęku przed konsekwencjami kazirodztwa. Wybrane fragmenty lub wątki dzieł literackich wyrażaja miłość chłopca i ukrywaja ją jednocześnie. Uwielbienie dla Hölderlina, Becketta, Johanny Schopenhauer czy Mozarta jest w powieści efektem sublimacji pożądania Madame. Tworzy się cały, mówiąc językiem Freuda, „szereg” czy „seria” obiektów zastępczych ${ }^{54}$, którą Lacan opisywał jako metonimicznie ujęty „łańcuch znaczących” - symboli odsyłających do innych symboli ${ }^{55}$. Ostatecznie chodzi o utraconą matkę, ale zostaje to zapomniane i przekształcone w język i kulturę.

Nie tylko bohater powieści posługuje się sublimacja, żeby móc zrezygnować z posiadania Madame i zamiast tego rozkoszować się poezją i muzyka, rozkoszować się stowem zamiast zakazaną rzeczq. Freud w eseju „Uwagi na temat dwóch zasad procesu psychicznego" przedstawił swoje rozumienie

${ }^{54}$ Zob. S. Freud, O szczególnym typie wyboru obiektu u mężczyzny, [w:] tegoż, Dzieła, t. V..., s. 171.

${ }^{55}$ Por. J. Lacan, dz. cyt., s. 118. 
myślenia w ogóle, w tym fantazjowania, ale także myślenia werbalnego jako formy zastępczej wobec motorycznego rozładowania popędu, charakterystycznego dla prymitywnej organizacji psychicznej niemowlęcia. Myślenie zastępuje więc działanie, zwłaszcza w sytuacjach, gdy działania trzeba się wyrzec - wtedy fantazja stanowi rekompensatę za wyrzeczenie. Sztuka w ogóle, wedle Freuda, stanowi specyficzny przykład uniwersalnego procesu przemieszczenia popędu z działania na fantazjowanie i mówienie ${ }^{56}$. Już na początku powieści Libera ujmuje tę zasadę w najzupełniej prosty, kolokwialny wręcz sposób, mówiąc o uczniach pożądających Madame: „To ogromne napięcie rozładowywano w gadaniu" (s. 51). To pozornie kolokwialne zdanie ujmuje całą istotę twórczości literackiej i rozwoju osobowości, a także w dużej mierze tworzenia kultury. Oczywiście - cała złożoność ludzkiej psychologii tkwi nie w tym, że rozładowujemy napięcie w gadaniu, ale $w$ jaki sposób to czynimy.

Powieść stanowi metaforę nie tylko sztuki samej w sobie, ale też szerzejkulturotwórczej aktywności człowieka, znowu - w rozumieniu Freudowskim. Stanowi ona nie tylko Bildungsroman, jak powieści o Wilhelmie Meistrze Goethego, którego lubił przywoływać Freud, czy powieści Manna, który lubił przywoływać Freuda. Bildung nie dotyczy tylko głównego bohatera, ale całej powieści jako sieci symboli, które absorbują prymitywną energię popędu i umożliwiają to samo czytelnikowi przez identyfikację. Sieć aluzji, odniesień i symboli w powieści Antoniego Libery połączona jest mocą Erosa, tego popędu, który łączy i tworzy, odraczając i odwracając nieuchronny rozpad i śmierć. Literatura nie jest bowiem kochana z jakichś abstrakcyjnych, intelektualnych powodów, ale, sugeruje Libera, jak kiedyś Freud, miłość ta ma swoje zakorzenienie w świecie popędów, które wyzwala i uczłowiecza. Chłopiec kocha Ren Hölderlina najpierw dlatego, że łączy się on z Madame i zastępuje mu ja, a zapamiętanie wiersza symbolizuje internalizację ukochanej. Potem jednak miłość zapomina o swym źródle i żyje sama dla siebie. W jakimś sensie wszystko, co kochamy, zastępuje matkę, lecz nie moglibyśmy tego kochać, gdybyśmy byli tego świadomi - wyparcie umożliwia wzniesienie się ponad indywidualną historię i gatunkową zwierzęcość człowieka.

${ }^{56}$ „Artysta to pierwotnie człowiek, który odwrócił się od rzeczywistości, albowiem nie był w stanie zaprzyjaźnić się z kierowanym pod jego adresem postulatem wyrzeczenia się zaspokojenia popędowego, to człowiek, który swe życzenia erotyczne i ambicjonalne zaspokaja w fantazji. Ale artysta tym się charakteryzuje, że potrafi znaleźć drogę powrotu z fantazji do rzeczywistości, a dzięki swemu talentowi umie przekuć fantazje na coś w rodzaju nowych form realności, które rodzaj ludzki honoruje jako cenne odzwierciedlenia rzeczywistości” (S. Freud, Uwagi na temat dwóch zasad..., s. 7-14, cytat na s. 12). Ten sam pogląd wyraża Freud również w: Wstę do psychoanalizy, przeł. S. Kemperówna, W. Zaniewicki, Warszawa 1994, s. 340-341. 
Energia tworzenia literatury jest jednak energią seksualna, choć w tym procesie-zdeseksualizowaną. Bohater/narrator, pisząc powieść o Madame, bierze ją bowiem w seksualne posiadanie, ale też i nie bierze, bo przecież przeżywa żałobę po tej, która utracił. Freud w Żałobie i melancholii zwraca uwagę, że utracony obiekt miłości jest wchłaniany przez inkorporację i identyfikację, co nie kończy się depresją tylko wtedy, gdy więcej jest miłości niż wrogości ${ }^{57}$. Nie tylko napisanie powieści jest identyfikacją z płodnościa pary rodzicielskiej - z Madame-Matka, kochająca zachodnią kulturę-ojca i z samym tym ojcem - bohater wraca też do szkoły i staje się nauczycielem, świadomie czując, że wchodzi w rolę swojej dawnej ukochanej i Muzy.

Dzięki pisaniu bohater rozwiązuje też problem narcystyczny. Kwestia konfrontacji z wymagajaca seksualnie matką zostaje przemieszczona sublimacyjnie na próbę oczarowania świata własną twórczością - tu publiczność jest kobieta, która pisarz próbuje zdobyć, olśnić i oczarować. Powieść kończy się nadzieja, że choć, wbrew sugestiom Madame, pisana po polsku, podbije świat zachodni, jeśli okaże się naprawdę wartościowa. Posiadanie Madame-Matki w realności byłoby narcystyczną trauma - posiadanie symbolicznego obiektu w fantazji, za sprawą literatury staje się narcystycznym spełnieniem, w którym ojciec nie jest wykluczony, ale staje się oparciem (w tym sensie, że kultura zachodnia staje się oparciem dla narratora). W końcowej scenie z uczniem, który mówi bohaterowi o krążącej po szkole legendzie, jakoby miał on w młodości romans z Madame, bohater w żartobliwy sposób przyjmuje fałsz legendy jako swego rodzaju prawdę mitu, fałsz realności jako prawdę fantazji i sublimacji. Miał przecież romans z Madame, a romansem tym jest/była/będzie powieść pod tymże tytułem.

\section{Wnioski}

Kluczem interpretacyjnym uczyniłem w niniejszych rozważaniach mit Hipolita i jego związki z mitem Edypa. Hipolit w klasycznym micie i jego poetyckich opracowaniach kończy w sposób przerażajacy - jego ciało zamienione jest w krwawy strzęp, a u Seneki ojciec nie jest nawet w stanie nawet ułożyć szczątków syna tak, by uformowały coś na kształt ludzkich zwłok. U Antoniego Libery zaś Hipolit zostaje ocalony od tej fragmentacji, od tej archaicznej masakry, stwórczą mocą literatury, mocą symbolizacji i sublimacji. Powieść staje się całościa, która przywraca zwłokom Hipolita integralność i spójność. Nawet u Racine'a, stroniącego od Senecjańskiego „ekscesu”, grozy i rozbudowanej retorycznej symboliki, młodzieniec staje

${ }^{57}$ S. Freud, Żałoba i melancholia, [w:] tegoż, Dzieła, t. VIII..., s. 147-159. 
w końcu naprzeciw otwartej otchłani morza i potwora, który z niej wychodzi, żeby walczyć i - przegrywa. Libera dokonuje jednak cudu - Hipolit wygrywa z potworem. Bohater Madame, jako reinterpretacja figury Hipolita-Edypa, nie tylko rozwiązuje zagadkę Sfingi, ale unika zabicia ojca i współżycia z matką przez akt mówienia i pisania, które są ekspresja tęsknoty. Jeden z rozdziałów Madame zatytułowany jest „Na początku było Słowo” ${ }^{8}$. W kontekście psychoanalizy i powyższych rozważań trzeba by powiedzieć raczej - na końcu jest słowo.

\section{BIBLIOGRAFIA}

Abraham K., A Short study of the development of the libido, viewed in the light of mental disorders, [w:] K. Abraham, Selected Papers, przeł. D. Bryan, A. Strachey, London 1927.

Abraham K., The Spider as a dream symbol, [w:] K. Abraham, Selected Papers, przeł. D. Bryan, A. Strachey, London 1927.

Bachofen J.J., Matriarchat. Studium na temat ginajkokracji świata starożytnego podtug natury religijnej i prawnej, przeł. R. Reszke, Warszawa 2007.

Bettelheim B., Cudowne i pożyteczne. O znaczeniach i wartościach baśni, przeł. D. Danek, Warszawa 2010.

Caldwell R., The psychoanalytic interpretation of Greek myth, [w:] Approaches to Greek Myth, ed. L. Edmunds, Baltimore-London 2014.

Chasseguet-Smirgel J., Creativity and Perversion, New York 1984.

Cichowicz S., Owoc słodkiej fikcji, „Nowe Książki” 1999, nr 1.

Dybel P., Urwane ścieżki. Przybyszewski - Freud - Lacan, Kraków 2000.

Edmunds L., Freud and the father: Oedipus complex and Oedipus myth, "Psychoanalysis and Contemporary Thought" 1985, nr 8.

Eliot T.S., Seneca in Elizabethan translation, [w:] T.S. Eliot, Selected Essays, London 1966.

Fakhry Davids M., Father in the internal world. From boy to man to father, [w:] The Importance of Fathers. A Psychoanalytic Re-evaluation, eds. J. Trowell, A. Etchegoyen, New York 2002.

Fenichel O., The Psychoanalytic Theory of Neurosis, New York 1995.

Ferenczi S., Thalassa: a Theory of Genitality, London 1989.

Freud A., Ego i mechanizmy obronne, przeł. M. Ojrzyńska, Warszawa 2012.

Freud S., 'Ja' $i$ 'to', [w:] S. Freud, Dzieta, t. VIII: Psychologia nieświadomości, przeł. R. Reszke, Warszawa 2009.

Freud S., Kultura jako źródło cierpien, [w:] S. Freud, Dzieła, t. IV: Pisma społeczne, przeł. R. Reszke, Warszawa 2009.

${ }^{58} \mathrm{Na}$ temat koncepcji słowa w Madame pisał między innymi P. Huelle (KPP $i$ duch Racine'a, „Tygodnik Powszechny” 1998, 39, s. 12). 
Freud S., Dlaczego wojna?, [w:] S. Freud, Dzieła, t. IV: Pisma społeczne, przeł. R. Reszke, Warszawa 2009.

Freud S., Fetyszyzm, [w:] S. Freud, Dzieła, t. VIII: Psychologia nieświadomości, Warszawa 2009.

Freud S., Kilka psychicznych skutków anatomicznej różnicy płci, [w:] S. Freud, Dzieła, t. V: Życie seksualne, przeł. R. Reszke, Warszawa 2009.

Freud S., Kulturowa moralność seksualna a wspótczesna nerwowość, [w:] S. Freud, Dzieła, t. IV: Pisma społeczne, przeł. R. Reszke, Warszawa 2009.

Freud S., Leonarda da Vinci wspomnienie z dzieciństwa, [w:] S. Freud, Dzieła, t. X: Sztuki plastyczne i literatura, przeł. R. Reszke, Warszawa 2009.

Freud S., Mojżesz Michała Anioła, [w:] S. Freud, Dzieła, t. X: Sztuki plastyczne i literatura, przeł. R. Reszke, Warszawa 2009.

Freud S., O dziecięcych teoriach seksualnych, [w:] S. Freud, Dzieła, t. V: Życie seksualne, przeł. R. Reszke, Warszawa 2009.

Freud S., O szczególnym typie wyboru obiektu u mężczyzny, [w:] S. Freud, Dzieła, t. V: Życie seksualne, przeł. R. Reszke, Warszawa 2009.

Freud S., Objaśnianie marzeń sennych, [w:] S. Freud, Dzieła, t. I, przeł. R. Reszke, Warszawa 2007.

Freud S., Popędy i ich losy, [w:] S. Freud, Dzieła, t. VIII: Psychologia nieświadomości, Warszawa 2009.

Freud S., Przyszłość pewnego złudzenia, [w:] S. Freud, Dzieła, t. IV: Pisma społeczne, przeł. R. Reszke, Warszawa 2009.

Freud S., Totem i tabu, [w:] S. Freud, Dzieła, t. IV: Pisma społeczne, przeł. R. Reszke, Warszawa 2009.

Freud S., Trzy rozprawy z teorii seksualnej, [w:] S. Freud, Dzieła, t. V: Życie seksualne, przeł. R. Reszke, Warszawa 2009.

Freud S., Upadek kompleksu Edypa, [w:] S. Freud, Dzieła, t. V: Życie seksualne, przeł. R. Reszke, Warszawa 2009.

Freud S., Uwagi na temat dwóch zasad procesu psychicznego, [w:] S. Freud, Dzieła, t. VIII: Psychologia nieświadomości, Warszawa 2009.

Freud S., Wstęp do psychoanalizy, przeł. S. Kemperówna, W. Zaniewicki, Warszawa 1994.

Freud S., Z historii nerwicy dziecięcej, [w:] S. Freud, Dzieła, t. VI: Dwie nerwice dziecięce, przeł. R. Reszke, Warszawa 2009.

Freud S., Żałoba i melancholia, [w:] S. Freud, Dzieła, t. VIII: Psychologia nieświadomości, Warszawa 2009.

Grunberger B., Narcissism: Psychoanalytic Essays, New York 1979.

Hadot P., The Present Alone is Our Happiness. Conversations with Jeannie Carlier and Arnold I. Davidson, przeł. M. Djaballah, Stanford 2009.

Huelle P., KPP i duch Racine’a, „Tygodnik Powszechny” 1998, nr 39.

Jung C.J., Symbole przemiany: analiza preludium do schizofrenii, przeł. R. Reszke, Warszawa 1998.

Kernberg O.F., Object-relations Theory and Clinical Psychoanalysis, New York 1976.

Klein M., Uwagi na temat niektórych mechanizmów schizoidalnych, [w:] M. Klein, Zawissć i wdzięczność, Pisma, t. III, przeł. A. Czownicka, H. Grzegołowska-Klarkowska, Gdańsk 2007. 
Kołakowski L., Główne nurty marksizmu, cz. 3: Rozkład, Poznań 2001.

Lacan J., Écrits. A Selection, przeł. B. Fink, New York-London 2002.

Lévi-Strauss C., Antropologia strukturalna, przeł. K. Pomian, Warszawa 2000.

Libera A., Madame, Kraków 2010.

Mann T., Czarodziejska góra, przeł. J. Kramsztyk, Wrocław 1995.

Markiewicz H., Literatura a mity, [w:] H. Markiewicz, Literaturoznawstwo i jego sqsiedztwa, Warszawa 1989.

Neumann E., Wielka Matka. Fenomenologia kobiecości, kształtowanie nieświadomości, Warszawa 2008.

Pucci P., Oedipus and the Fabrication of the Father: Oedipus Tyrannus in modern criticism and philosophy, Baltimore 1992.

Roisman H.M., The Veiled Hippolytus and Phaedra, "Hermes" 1999, nr 127, 4.

Stabryła S., Mit, człowiek, literatura, Warszawa 1991.

Szczuka K., Forma i chtopiec, „Res Publica Nowa” 1999, nr 1-2 [124-125].

Turkle S., Psychoanalytic Politics: Freud's French Revolution, New York 1978.

Ulicka D., Czekanie na opowieść, „Nowe Książki” 1999, nr 1.

Whitebook, J. Perversion and Utopia: Study in Psychoanalysis and Critical Theory, Cambridge 1995.

Żart, ironia, muzyka i głębsze znaczenie. Z Antonim Libera rozmawia Władysław Rajcher, „Nowe Książki” 1999, nr 1. 
